\title{
A probabilistic risk assessment for the vulnerability of the European carbon cycle to weather extremes: the ecosystem perspective
}

\author{
S. Rolinski ${ }^{1}$, A. Rammig ${ }^{1}$, A. Walz ${ }^{2}$, W. von Bloh ${ }^{1}$, M. van Oijen ${ }^{3}$, and K. Thonicke ${ }^{1}$ \\ ${ }^{1}$ Potsdam Institute for Climate Impact Research, Telegraphenberg, PO Box 6012 03, 14412 Potsdam, Germany \\ ${ }^{2}$ Potsdam University, Karl-Liebknecht-Str. 24-25, 14476 Potsdam-Golm, Germany \\ ${ }^{3}$ Centre for Ecology \& Hydrology Edinburgh, Bush Estate, Penicuik, Midlothian, EH26 0QB, UK
}

Correspondence to: S. Rolinski (susanne.rolinski@pik-potsdam.de)

Received: 27 March 2014 - Published in Biogeosciences Discuss.: 30 June 2014

Revised: 2 February 2015 - Accepted: 20 February 2015 - Published: 19 March 2015

\begin{abstract}
Extreme weather events are likely to occur more often under climate change and the resulting effects on ecosystems could lead to a further acceleration of climate change. But not all extreme weather events lead to extreme ecosystem response. Here, we focus on hazardous ecosystem behaviour and identify coinciding weather conditions. We use a simple probabilistic risk assessment based on time series of ecosystem behaviour and climate conditions. Given the risk assessment terminology, vulnerability and risk for the previously defined hazard are estimated on the basis of observed hazardous ecosystem behaviour.

We apply this approach to extreme responses of terrestrial ecosystems to drought, defining the hazard as a negative net biome productivity over a 12 -month period. We show an application for two selected sites using data for 1981-2010 and then apply the method to the pan-European scale for the same period, based on numerical modelling results (LPJmL for ecosystem behaviour; ERA-Interim data for climate).

Our site-specific results demonstrate the applicability of the proposed method, using the SPEI to describe the climate condition. The site in Spain provides an example of vulnerability to drought because the expected value of the SPEI is 0.4 lower for hazardous than for non-hazardous ecosystem behaviour. In northern Germany, on the contrary, the site is not vulnerable to drought because the SPEI expectation values imply wetter conditions in the hazard case than in the non-hazard case.
\end{abstract}

At the pan-European scale, ecosystem vulnerability to drought is calculated in the Mediterranean and temperate region, whereas Scandinavian ecosystems are vulnerable under conditions without water shortages. These first model- based applications indicate the conceptual advantages of the proposed method by focusing on the identification of critical weather conditions for which we observe hazardous ecosystem behaviour in the analysed data set. Application of the method to empirical time series and to future climate would be important next steps to test the approach.

\section{Introduction}

Climate change is expected to have impacts on the productivity and stability of ecosystems worldwide. When ecosystem productivity is reduced, atmospheric $\mathrm{CO}_{2}$ concentrations can be further enhanced and thus reinforce climate change. Especially extreme weather events (as perceived in Seneviratne et al., 2012), which are expected to become more frequent and intense (Field et al., 2012; Coumou and Rahmstorf, 2012), are likely to severely impact terrestrial ecosystems (Reichstein et al., 2013; Zscheischler et al., 2014a).

Drought is the one dominant weather extreme that has already led to large-scale biomass loss over the past decades in European ecosystems (Ciais et al., 2005) and that is expected to increase rapidly in magnitude and frequency with further climate change (Zscheischler et al., 2014a). Many studies investigated the impact of drought on terrestrial ecosystems including monitoring (e.g. Buentgen et al., 2011; Ciais et al., 2005), experimental (e.g. Eilmann et al., 2011; Misson et al., 2011) and model-based research (e.g. Cherwin and Knapp, 2012). However, not all droughts lead to extreme ecosystem responses. To disentangle the connections between extremes in the biosphere and the environment, Smith (2011) proposed 
a concept that subdivides situations according to their extremeness both on the physical and the biological side. Improving our understanding of the weather conditions under which extreme ecosystem response occurred is thus an imperative which needs to be advanced in parallel to further investigating the preconditions that make an ecosystem particular prone to extreme response (Frank et al., accepted).

Probabilistic risk assessment (PRA), initially developed in engineering (e.g. Wall, 1969), has also been frequently applied in ecology (e.g. in population ecology by Diez et al., 2012; Hope, 2000; Regan et al., 2003; Wilson et al., 2009). In 2013, Van Oijen et al. used PRA successfully to deduce vulnerability and risk from drought and heatwaves to European spruce forest. They quantified the vulnerability as the expected impact of drought and heatwaves on the carbon storage of the forest, and deduced risk by incorporating the probability of occurrence. Thus, they defined the extreme weather event as the hazard, and then investigate the related ecosystem response. Changing the perspective and searching for the drought conditions under which extreme ecosystem response occurs, we build on the same concept of PRA, but define the hazard as the extreme ecosystem response and then identify the critical weather conditions that co-occurred with the extreme ecosystem response. In line with Van Oijen et al. (2013), vulnerability is then quantified by determining the difference between mean climate conditions provoking either hazardous or non-hazardous ecosystem responses, and risk by incorporating the probability of the hazardous event.

We further adapt this initial ecosystem-focused PRA for the vulnerability and risk assessment of drought-induced net biomass loss by specifying response and climate variables, and apply it at the site and pan-European scale.

Hence, the aims of this study comprise the following:

1. developing a PRA that enables us to better understand the meteorological conditions under which extreme ecosystem responses occurs, namely loss of biomass under drought conditions;

2. adapting the PRA for vulnerability and risk from drought using net biomass loss as a hazard;

3. providing a first illustrative application of the adapted PRA on the site-scale; and finally,

4. applying the methods to estimate the vulnerability and risk of terrestrial ecosystems to loose biomass and therefore turn into a source of carbon dioxide at the PanEuropean scale.

According to these objectives, we first develop a general PRA focusing on the ecosystem response to quantify ecosystem vulnerability and risk from climate conditions by defining a discrete and ecologically meaningful threshold for hazardous ecosystem behaviour. We further adapt the general PRA to assess vulnerability and risk specifically from drought. Using modelled ecosystem data for a 30-year period, we then apply the adapted PRA to investigate vulnerability and risk from drought for two individual sites within Europe. And finally, we extend the application to ecosystem at the pan-European scale to identify and quantify vulnerability to drought and associated risk.

\section{General framework for probabilistic risk assessment (PRA) from the ecosystem perspective}

Since impacts of extreme weather on ecosystems are not always direct and uniform, but can also have indirect and/or lagged effects (Barbeta et al., 2013; Martin-StPaul et al., 2013), other measures are required that subsume the various ecosystem responses. Single (extreme) events can influence particular ecosystem patterns or functions but allow for a quick recovery. The question, however, is how ecosystems may become vulnerable over longer timescales of several years to decades. We rearrange the approach of Van Oijen et al. (2013), and define hazardous conditions from an ecosystem perspective to quantify the probability of weather conditions determining ecosystem vulnerability. To calculate vulnerability from the ecosystem perspective, we define an ecosystem variable sys and an environmental variable env (Fig. 1a). A threshold of the ecosystem variable sys defines the hazard and divides the data set into hazardous (haz) and non-hazardous conditions (nonhaz) (Fig. 1b). Ecosystem vulnerability $\left(V_{\mathrm{E}}\right)$ is then determined by conditional probabilities, i.e. the expectation value $(E)$ of $e n v$ under nonhazardous and hazardous conditions of sys (Eq. 1, Fig. 1c)

$V_{\mathrm{E}}=E(e n v \mid s y s$ nonhaz $)-E(e n v \mid s y s \mathrm{haz})$

based on conditional expectation values

$E(e n v \mid 0)=\int e n v \mathbb{P}(e n v \mid 0) \mathrm{d} e n v$

with probability $\mathbb{P}$ of env under the specified condition o. Ecosystem vulnerability $V_{\mathrm{E}}$ (Eq. 1) in our assessment is the average deviation of the environmental variable under hazardous ecosystem conditions from values under nonhazardous ecosystem conditions (Fig. 1d). $V_{\mathrm{E}}$ and risk $\left(R_{\mathrm{E}}\right)$ are therefore expressed in the unit of the environmental variable and describe the deviations in the weather conditions co-occurring with hazards in the ecosystem. The probability of the hazard occurrence $\mathbb{P}_{H}$ is given by the relative size of the hazard group, i.e. the number of data points for hazardous conditions $N_{\text {haz }}$ divided by the total number of values $N$; resulting in $\mathbb{P}_{\mathrm{H}}=N_{\mathrm{haz}} / N$. The corresponding risk $\left(R_{\mathrm{E}}\right)$ is then defined as the product of the vulnerability of the ecosystem and the hazard probability (Eq. 3, Fig. 1e),

$$
\begin{aligned}
R_{\mathrm{E}} & =V_{\mathrm{E}} \cdot \mathbb{P}_{\mathrm{H}} \\
& =E(\text { env } \mid \text { sys nonhaz })-E(\text { env })
\end{aligned}
$$



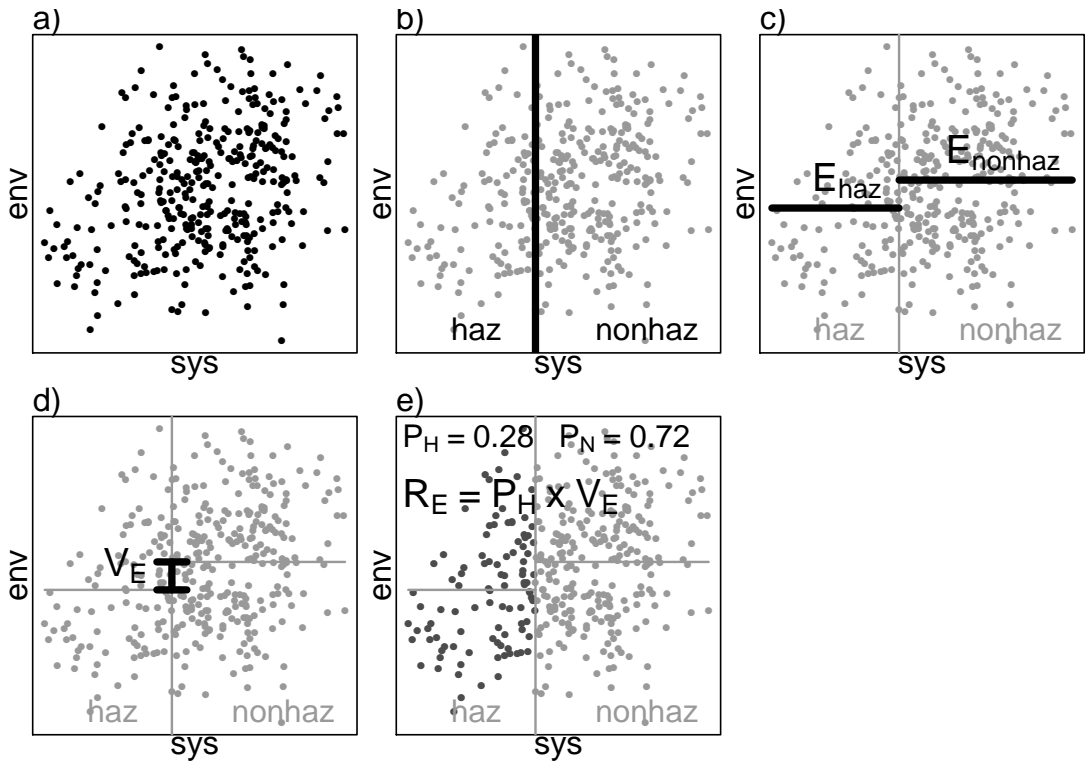

Figure 1. Schematic representation of ecosystem vulnerability and risk determination. (a) regarding sys as independent and env as dependent variable, (b) dividing the data set according to the defined hazard for $s y s$ into hazardous and non-hazardous subsets, (c) calculating expectation values $E_{\mathrm{haz}}$ and $E_{\mathrm{nonhaz}}$ of $e n v$ for the two data subsets, (d) determining $V_{\mathrm{E}}$ as the difference of the expectation values (Eq. 1), (e) determining $R_{\mathrm{E}}$ as the product of $V_{\mathrm{E}}$ and the probability of the hazard occurrence $\mathbb{P}_{\mathrm{H}}$ (Eq. 3).

which can be replaced by the respective expectation values for hazardous and non-hazardous conditions combining Eqs. (1) and (2). On the one hand, $R_{\mathrm{E}}$ reflects the usual perception of risk as the realized vulnerability. On the other hand, it cannot be interpreted as expected damage since it is related to the environmental variable and does not express a property of the ecosystem such as carbon loss.

In the ecosystem vulnerability approach, high values of $V_{\mathrm{E}}$ and $R_{\mathrm{E}}$ denote high vulnerability and risk towards the respective environmental variable because the ecosystem hazard (e.g. carbon loss) occurs when env differs considerably from situations when the ecosystem accumulates carbon (see Sect. 5.1). The distance between the expectation values reveals the potential impact of $e n v$ on the ecosystem. It has to be stressed that the method is not suitable for, and not targeting at, the quantification of effects of single extreme events. By using probability distributions and their expectation values, the long-term effect of the entire ecosystem in relation to extremes occurring on climatic timescales is evaluated.

Our approach is completely general in the sense that we can describe the vulnerability of any ecosystem variable (see Sect. 2.1), and use any threshold as the criterion for hazardous conditions. It can be applied to measured data as well as to simulation results from ecosystem models. Whereas an application to experimental data allows for the evaluation of the behaviour of the studied ecosystem, the application to simulation results examines the responses of the model to climatic drivers. The prerequisite for the application is the availability of sufficient data points for env and sys so that probability distributions can be derived. This facilitates the application to model results and currently limits the scope for measured data.

\subsection{Data sources for environmental variable env}

Environmental variables (env) which can be chosen for the probabilistic risk assessment are monthly values of the Standardized Precipitation Evapotranspiration Index, SPEI (-), but also monthly values of precipitation, temperature, or consecutive dry days with precipitation below $1 \mathrm{~mm}$. The SPEI is a recent extension of the Standardized Precipitation Index by the influence of temperature on the potential evapotranspiration (Vicente-Serrano et al., 2010) and was calculated with function spei of R package SPEI (R Development Core Team, 2014) with a 3-monthly averaging interval. SPEI values have an average of 0 and are regarded as an indicator of drought below -1.0 or water surplus above 1.0.

In our case, we choose $S$ as monthly SPEI values and give results for other env in appendix A. We use env values from 1981 to 2010 (see Sect. 3.1).

\subsection{Choice of ecosystem variable sys}

To derive the system variable sys, we use results of the global, dynamic process-based vegetation model LPJmL (see Sect. 3.2). For the analysis, daily meteorological data described in Sect. 3.1 are used as forcing data for the simulations with LPJmL. A detailed protocol of the model set up is given in Sect. 3.3. All processes, including fire, are simulated at a daily resolution in this study, so that extreme con- 
ditions contained in the climate input data set will have an impact on the simulated ecosystem variables. To derive sys, we select monthly values of net primary production (NPP), heterotrophic respiration (Rh) and burned biomass (BB) (all given in $\mathrm{gC} \mathrm{m}^{-2}$ month $^{-1}$ ) from which net biome production (NBP) is calculated (Eq. 4).

$\mathrm{NBP}=\mathrm{NPP}-\mathrm{Rh}-\mathrm{BB}$

In order to detect hazardous conditions outside their average seasonal dynamics and to include lagged effects of the ecosystem in the months following after the extreme weather event, a moving time window of 12 months is defined, during which NBP values were considered. The system variable sys for month $i$ in the period of $m$ years is chosen as the sum of NBP over the 12-month moving window including month $i$ and the following 11 months (Eq. 5).

$s y s_{i}=\sum_{k=i}^{i+11} \mathrm{NBP}_{k} \quad$ for $i \in(1, \ldots, m \times 12)$.

With this definition, $s y s_{i}$ integrates over a 12-month period but does not refer to the calendar year. It eliminates the effect of seasonal dynamics within NBP, independent of differences in growing seasons between biomes and regions. The choice of the moving time-window aims at the consideration of long-term impacts of weather extremes and the exclusion of seasonal effects, for example by plants in seasonally dry ecosystems that are adapted to dry summer months. Moving the one-year window month by month further accounts for droughts of varying duration. The $e n v$ variable SPEI with an averaging interval of 3 months represents a medium-term situation on the subseasonal scale (Vicente-Serrano et al., 2010, 2012). The combination with the ecosystem condition over a cycle of 12 months allows for the identification of responses which exceed seasonal variations.

We define a hazard as a month $i$ for which the system variable $s y s_{i}$ is negative $\left(s y s_{i}<0\right)$, i.e. the ecosystem is a net source of carbon for the following 12-month period. Hence, the performance of the vegetation model is decisive for the classification as hazardous or not, but only the sign of the carbon balance and not the extent of the reaction. Since the magnitude of the vulnerability and risk values determined by Eqs. (1) and (3) result from the average deviation of the meteorological variables, it does play a role whether the processes in the model include or react to feedbacks important in drought situations, but the exact representation of the magnitude of the response does not play a role in our approach.

\section{Material and methods}

In order to demonstrate the applicability of the concept, we first calculate ecosystem vulnerability and risk for two sites in Germany and Spain and secondly quantify $V_{\mathrm{E}}$ and $R_{\mathrm{E}}$ on the European scale. For both, we use meteorological data as
Table 1. Coordinates of European geographical zones (latitudes, longitudes) according to the SREX classification (NEU: Northern Europe, CEU: Central Europe, MED: Mediterranean) (IPCC, 2012).

\begin{tabular}{llll}
\hline & NEU (11) & CEU (12) & MED (13) \\
\hline SW & $\left(48^{\circ} \mathrm{N}, 10^{\circ} \mathrm{W}\right)$ & $\left(45^{\circ} \mathrm{N}, 10^{\circ} \mathrm{W}\right)$ & $\left(30^{\circ} \mathrm{N}, 10^{\circ} \mathrm{W}\right)$ \\
$\mathrm{NW}$ & $\left(75^{\circ} \mathrm{N}, 10^{\circ} \mathrm{W}\right)$ & $\left(48^{\circ} \mathrm{N}, 10^{\circ} \mathrm{W}\right)$ & $\left(45^{\circ} \mathrm{N}, 10^{\circ} \mathrm{W}\right)$ \\
$\mathrm{NE}$ & $\left(75^{\circ} \mathrm{N}, 40^{\circ} \mathrm{E}\right)$ & $\left(61.32^{\circ} \mathrm{N}, 40^{\circ} \mathrm{E}\right)$ & $\left(45^{\circ} \mathrm{N}, 40^{\circ} \mathrm{E}\right)$ \\
$\mathrm{SE}$ & $\left(61.32^{\circ} \mathrm{N}, 40^{\circ} \mathrm{E}\right)$ & $\left(45^{\circ} \mathrm{N}, 40^{\circ} \mathrm{E}\right)$ & $\left(30^{\circ} \mathrm{N}, 40^{\circ} \mathrm{E}\right)$ \\
\hline
\end{tabular}

environmental variable env (Sect. 2.1) and the results of a dynamic vegetation model as system variable sys (Sect. 2.2) with a spatial resolution of $0.25^{\circ} \times 0.25^{\circ}$ across Europe ( $\sim 17800$ grid cells). This approach enables a consistent analysis since the meteorological data were used as forcing for the vegetation model and as env. We analyse a current period (1981 to 2010) and use the European regions defined by SREX (IPCC, 2012) for regional aggregation (Table 1).

\subsection{Input data}

We use WATCH-ERA-Interim daily climate data at $0.25^{\circ} \times 0.25^{\circ}$ grid cell resolution to the European spatial domain $\left(29.125\right.$ to $71.375^{\circ} \mathrm{N}$ and -23.875 to $\left.45.375^{\circ} \mathrm{E}\right)$. This data set is based on downscaled WATCH climate data (Weedon et al., 2011) for the years 1901-1978 and extended to 2010 using downscaled ERA-Interim climate data (Dee et al., 2011) (see details in Beer et al., 2014). The variables in the daily climate data set include temperature (minimum and maximum daily values), precipitation, wind speed, and longwave and short-wave downward radiation flux. Annual atmospheric $\mathrm{CO}_{2}$ concentrations for 1901-2010 are based on data from ice-core records and NOAA atmospheric observations (Keeling and Whorf, 2005).

\subsection{Description of the vegetation model LPJmL}

LPJmL simulates carbon and water cycles as well as vegetation growth dynamics depending on daily climatic conditions and soil texture. Natural vegetation is represented in LPJmL at the biome level by nine plant functional types (PFTs) (Sitch et al., 2003). The model calculates closed balances of carbon fluxes (gross primary production, auto- and heterotrophic respiration) and pools (in leaves, sapwood, heartwood, storage organs, roots, litter and soil), as well as water fluxes (interception, evaporation, transpiration, snowmelt, run-off, discharge) (Gerten et al., 2004; Rost et al., 2008). Photosynthesis is simulated following the Farquhar model approach (Farquhar et al., 1980; Farquhar and Von Caemmerer, 1982). Processes of carbon assimilation and water consumption are parameterized on the leaf level and scaled to the ecosystem level. Carbon and water dynamics are closely linked so that the effects of changing temperatures, declin- 
ing water availability and rising $\mathrm{CO}_{2}$ concentrations are accounted for and their net effect can be evaluated (Gerten et al., 2004, 2007). Physiological and structural plant responses determine water requirements and consumption.

LPJmL has been used in various studies where the hydrological cycle and the plants reaction to water shortage were a major factor. In these studies, different affected processes were investigated including run-off (Haddeland et al., 2011; Murray et al., 2013), and local carbon fluxes and water flux dynamics (see comparison with eddy-flux tower measurements for the northern latitudes in Figs. S2 and S3 in the Supplement, Schaphoff et al., 2013). Furthermore, system response to drought stress of the LPJmL model has been compared to observational data for the European summer 2003 climate anomaly (Reichstein et al., 2007). On the European scale, coincidence pattern of NPP reductions were compared to tree ring data (Rammig et al., 2015) which revealed a strong sensitivity of the model to extremely low precipitation.

Thus, when the climate forcing includes prolonged periods of drought and/or high temperatures, these have direct effects on carbon assimilation and water stress in the model. LPJmL simulates physiological processes depending on the current climate conditions and their history which is reflected in the composition of the plant community and their carbon stocks accumulated so far. Hence, the response of the model to a certain extreme event is not always the same. Biological mechanisms responding to extreme events include net primary productivity driven by climate conditions and by atmospheric $\mathrm{CO}_{2}$ concentration which changes the amount of leaf biomass simulated for each PFT. Under rising atmospheric $\mathrm{CO}_{2}$ concentrations, stomatal conductance decreases, leading to higher water-use efficiency which can buffer increasing drought impacts. Another example of physiological adaptation is carbon allocation to new roots, which is an adaptive response to increasing soil water limitations. Unproductive individuals with a low growth rate are likely to die. The resulting model response is a combination of the climate conditions and of the characteristics of the present PFTs. Competition between PFTs due to differences in their performance under given climate conditions, can lead to changes in vegetation composition as less adapted PFTs can be out-competed and replaced. Subsequently to changes in vegetation composition, i.e. changes in the PFT distribution, changes in the productivity and the respective carbon fluxes can also be quantified. This applies to long-term climate trends as well as interannual climate variability, including the impact of extreme events. Therefore, the LPJmL model is indeed capable of capturing dynamic responses to, for example, single or consecutive drought events.

Fire is simulated within the process-based submodule SPITFIRE (Thonicke et al., 2010). Bedia et al. (2012) emphasize the importance of using daily maximum temperature in fire risk calculation to better capture extreme risk situations. The Nesterov Index (Nesterov, 1949), used to calcu- late fire risk in SPITFIRE, considers daily maximum temperature. Given the daily resolution of the input data set, the model should respond to prolonged drought and heat. Vegetation re-growth on burnt areas, simulated by SPITFIRE, depends on respective tree seedling performance and grass establishment under given climate conditions and follows the algorithms as described in the LPJmL model. Biomass burnt (BB) result from dead and live fuel consumption in surface fires and from crown scorching (Thonicke et al., 2010) and is included in the carbon balance NBP (Eq. 4).

The suitability of the LPJmL framework for vegetation and water studies has been demonstrated by validating simulated phenology (Bondeau et al., 2007), river discharge (Gerten et al., 2004; Biemans et al., 2009), soil moisture (Wagner et al., 2003), evapotranspiration (Sitch et al., 2003; Gerten et al., 2004) and carbon stored in litter biomass on the ground for temperate and boreal European ecosystems (Evangeliou et al., 2015).

\subsection{Modelling protocol}

For deriving the system variable sys, LPJmL simulations were performed with natural vegetation. In order to derive equilibrium fluxes between soil and vegetation, 1000-year spinup were simulated by using the climatic forcing from 1901 to 1930 in repetitive loops. The transient run from 1901 to 2010 was started by a further spinup period of 30 years. Climate forcing consisted of the WATCH-ERA-Interim climate data described in Sect. 3.1. Data for the soil properties (Sitch et al., 2003) and for lightning, human population density and human ignition (Thonicke et al., 2010) were regridded from a spatial resolution of $0.5^{\circ} \times 0.5^{\circ}$ to $0.25^{\circ} \times 0.25^{\circ}$.

\section{Results}

\subsection{Determination of ecosystem vulnerability and risk to drought: two examples at site-scale}

For the detailed calculation of ecosystem vulnerability, we chose two sites in Europe with different climatic conditions. In site 1 in northern Germany (Fig. 2a) the probability for a hazardous ecosystem condition (i.e. sys $<0$ ) for the period 1981 to 2010 is 0.25 , i.e. 80 of 360 data points are in the hazard group. The expectation value of the chosen env, the drought index SPEI, is 0.34 for data points with sys $<0$ (hazard case) and -0.09 for those with $s y s \geq 0$ (non-hazard case). The difference between both sets of SPEI values is significant ( $p$ value for statistical significance $<0.01$ ) and results in negative $V_{\mathrm{E}}$ and $R_{\mathrm{E}}$ (Fig. 2c). Thus, site 1 is not vulnerable to drought but to wet conditions. Due to the infrequent hazard occurrence, the corresponding risk is low.

In the second site in Spain, the probability for $s y s<0$ in the period 1981 to 2010 is much higher (50\%, Fig. 2b). The expectation value for SPEI values in the hazard group is -0.19 and 0.22 in the non-hazard group. The two sets of 

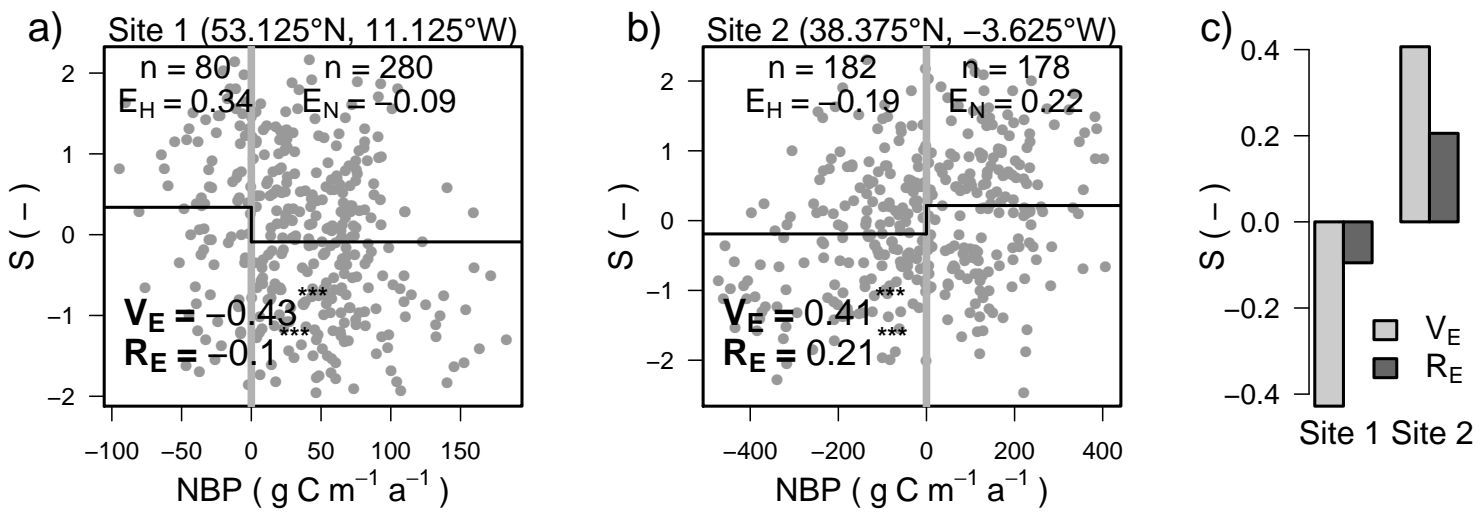

Figure 2. Scatterplots of sys variable $\mathrm{NBP}\left(\mathrm{g} \mathrm{C} \mathrm{m}^{-2} \mathrm{a}^{-1}\right)$ against $e n v$ variable SPEI (dimensionless) with monthly values from 1981 to 2010 for 2 sample grid cells in Europe: (a) northern Germany $\left(53.125^{\circ} \mathrm{N}, 11.125^{\circ} \mathrm{W}\right)$ and (b) Spain $\left(38.375^{\circ} \mathrm{N}, 3.625^{\circ} \mathrm{E}\right)$. Vertical lines denote the threshold value for the hazard and horizontal lines the expectation values for the respective env variable in the hazard $\left(E_{\mathrm{H}}\right)$ and the non-hazard case $\left(E_{\mathrm{N}}\right)$. Resulting expectation values, $V_{\mathrm{E}}$ and the frequency of data points in both groups are given (dimensionless numbers). Significance level of the Welch $t$ test between both groups is indicated for $V_{\mathrm{E}}$. (c) Calculated $V_{\mathrm{E}}$ and $R_{\mathrm{E}}$ values with negative sign for site 1 (vulnerable to wet conditions) and positive for site 2 (vulnerable to drought).
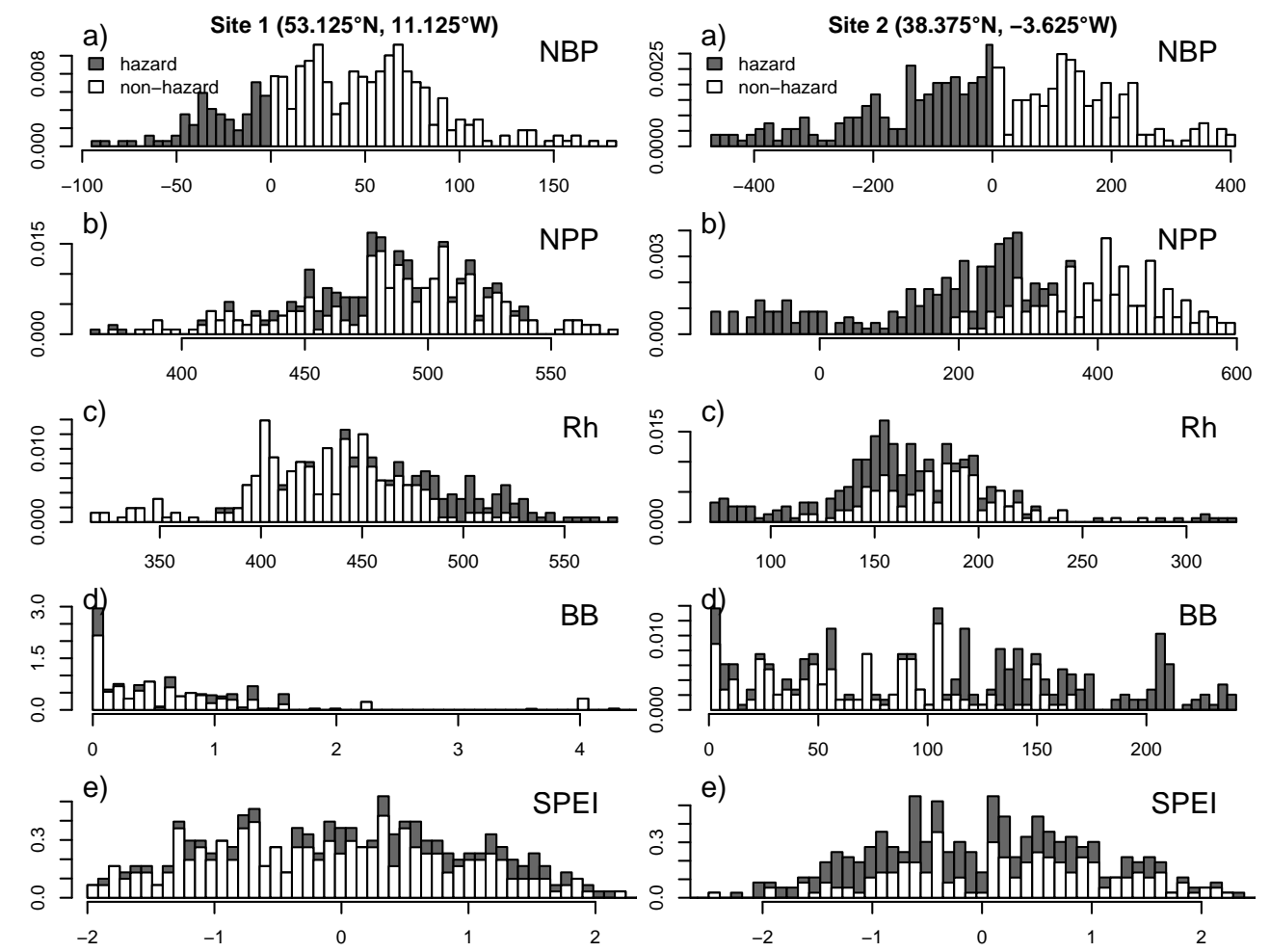

Figure 3. Probability distributions of NBP (a) and its contributions NPP (b), Rh (c), and BB (d) (all in $\mathrm{gC} \mathrm{m}^{-2} \mathrm{a}^{-1}$ ) and SPEI values (e) for sites 1 (left) and 2 (right) (see Fig. 2). Dark shading denotes values in the hazard group, white shading in the non-hazard group.

SPEI values are significantly different $(p<0.001)$. Here, $V_{\mathrm{E}}$ and $R_{\mathrm{E}}$ are positive (Fig. 2c). Site 2 is vulnerable to drought, meaning that carbon losses from the ecosystem occur when SPEI is 0.4 units lower than in situations when the ecosystem is accumulating carbon. The corresponding risk value of 0.2 is in this case lower than the vulnerability of 0.41
(Fig. 2b) and expresses the not fully utilized vulnerability potential because such extremes occur less often. Therefore, calculated risk values cannot be related directly to the severity of drought conditions, but relates ecosystem vulnerability to the hazard occurrence. 
Multiple processes can be responsible for hazardous NBP. Disentangling the carbon balance components NPP, Rh and $\mathrm{BB}$ under hazardous and non-hazardous conditions is one way to provide this insight. For site 1 in Germany, the distribution of NBP (Fig. 3a, left) is centred around $70 \mathrm{gC} \mathrm{m}^{-2} \mathrm{a}^{-1}$ with negative values mostly above $-50 \mathrm{gC} \mathrm{m}^{-2} \mathrm{a}^{-1}$. These data points are characterized by low net primary productivity (NPP, Fig. 3b, left) and high heterotrophic respiration (Rh) above $480 \mathrm{gC} \mathrm{m}^{-2} \mathrm{a}^{-1}$ (Fig. 3c, left). Biomass burnt (BB) is low (Fig. 3b, left) and does not differ between hazard and non-hazard groups. The defined hazard (negative NBP) is here occurring when SPEI values are rather high (Fig. 3e, left). In these situations, precipitation (and therefore, soil moisture) is above average, and radiation is below average (see area 1 in Fig. B2f, h).

At site 2 in Spain, mostly grasses grow with a low coverage of temperate evergreen trees. Negative NBP (Fig. 3a, right) is associated with low NPP (Fig. 3b, right), slightly lower Rh (Fig. 3c, right) and high BB (Fig. 3d, right). In the hazard case, precipitation is reduced substantially (see area 2 in Fig. B3f) so that NPP is water-limited and fire is often occurring. The positive $V_{\mathrm{E}}$ value for site 2 reflects the impact of drought on the NBP.

\subsection{Pan-European ecosystem vulnerability and risk to drought}

When applying the ecosystem vulnerability concept to the pan-European scale under current climate (1981-2010, Fig. 4a), we find vulnerable ecosystems predominantly in southern Europe $\left(V_{\mathrm{E}}>0.6\right)$. The border region of Ukraine, Belarus and Russia is most pronounced with positive $V_{\mathrm{E}}$ values of more than 0.4 . Reduced precipitation and slightly enhanced temperatures decrease photosynthesis and increase heterotrophic respiration in this forest area (area 3 in Appendix $\mathrm{B}) . V_{\mathrm{E}}$ above 0.4 is also determined in the mountainous regions of Macedonia and Albania. Weather conditions are extremely variable and lead to an open forest ecosystem. Reoccurring drought conditions do not allow for an accumulation of carbon in the biosphere and soil respiration enhances the loss of carbon during hazard occurrence (area 4 in Appendix B). In the boreal zone, $V_{\mathrm{E}}$ is negative meaning that those ecosystems are not vulnerable to drought. Comparing the expectation values of the hazard conditions, allows to reflect on the realized vulnerability, i.e. the risk $R_{\mathrm{E}}$ for carbon loss (Eq. 3). The corresponding $R_{\mathrm{E}}$ (Fig. $4 \mathrm{~b}$ ) shows highest values in northern Africa (0.4) followed by 0.2 in the Mediterranean, the Balkan Peninsula and Ukraine.

Having described regions and conditions being vulnerable (positive $V_{\mathrm{E}}$ ), large regions in Europe show vulnerability values around zero or are even negative. Extensive areas in the temperate region have $V_{\mathrm{E}}$ values close to zero which are not significant (areas not marked by dots in Fig. 4a) while in northern regions even negative values are widespread. We determine the spatial extent of vulnerable areas (positive $V_{\mathrm{E}}$ )
Table 2. Ecosystem vulnerability $V_{\mathrm{E}}$ and risk $R_{\mathrm{E}}$ (mean value \pm standard deviation) and percentage of affected area (\%) in Europe and in the SREX regions (Table 1$)$ of yearly carbon loss $(\mathrm{NBP}<0)$ to the $e n v$ variable $S(-)$ for significant cells. Bold numbers denote high positive values (mean value $>$ standard deviation).

\begin{tabular}{lccr}
\hline Region & $V_{\mathrm{E}}$ & $R_{\mathrm{E}}$ & affected area \\
\hline EU & $0.1 \pm 0.3$ & $0.08 \pm 0.17$ & 21.5 \\
NEU & $-0.3 \pm 0.1$ & $-0.14 \pm 0.07$ & 1.0 \\
CEU & $0.1 \pm 0.3$ & $0.07 \pm 0.14$ & 20.1 \\
MED & $\mathbf{0 . 3} \pm 0.2$ & $\mathbf{0 . 1 7} \pm 0.09$ & 52.7 \\
\hline
\end{tabular}

in Europe. For $24 \%$ of the European area, positive $V_{\mathrm{E}}$ values and significant differences between hazard and non-hazard groups of data are determined. In the southern region, this holds for $53 \%$ of the grid cells, whereas this percentage is smaller for the temperate and the northern regions (Table 2). Near or below zero $V_{\mathrm{E}}$ values are calculated for $58 \%$ of the European area $(89 \%$ for NEU, $49 \%$ for CEU and $13 \%$ for MED, SREX regions according to Table 1). Here, the ecosystem hazard occurs but can not be ascribed to drought.

Reasons for negative $V_{\mathrm{E}}$ could be (1) the ecosystem hazard is not explained by the selected $e n v$ variable and a further $e n v$ has to be identified, or (2) the range of the expected value chosen for the analysed env is not appropriate, e.g. high SPEI values are more damaging for the ecosystem than low values (see 2.1). Negative $V_{\mathrm{E}}$ values hardly occur in southern Europe ( $1 \%$ of the area), but frequently in the temperate $(11 \%)$ and northern $(32 \%)$ zones.

When comparing zonal averages of $V_{\mathrm{E}}$ according to the SREX regions (Table 1), ecosystem vulnerability to drought is high in the Mediterranean region (MED) with $53 \%$ of the region affected and showing the highest risk compared to other SREX regions (Table 2). Positive $V_{\mathrm{E}}$ values for most of central Europe (CEU, $20 \%$ affected) indicate widespread vulnerability to water shortage. Northern Europe (NEU) is characterized by mostly negative $V_{\mathrm{E}}$ affecting a negligible part of the region. Here, risk values are also relatively high because of more frequent hazard occurrence.

\section{Discussion}

\subsection{The concept of ecosystem vulnerability}

The proposed method allows for the quantification of the vulnerability and the associated risk of ecosystems to environmental drivers. This is also possible with other methods (Van Oijen et al., 2013, 2014), but our approach differs in that hazards are defined ecologically rather than meteorologically. From our ecosystem perspective, it is not necessary to assume thresholds for a weather extreme situation such as extreme temperature or precipitation. Instead the ecosystem vulnerability concept proposed in this paper subsumes 

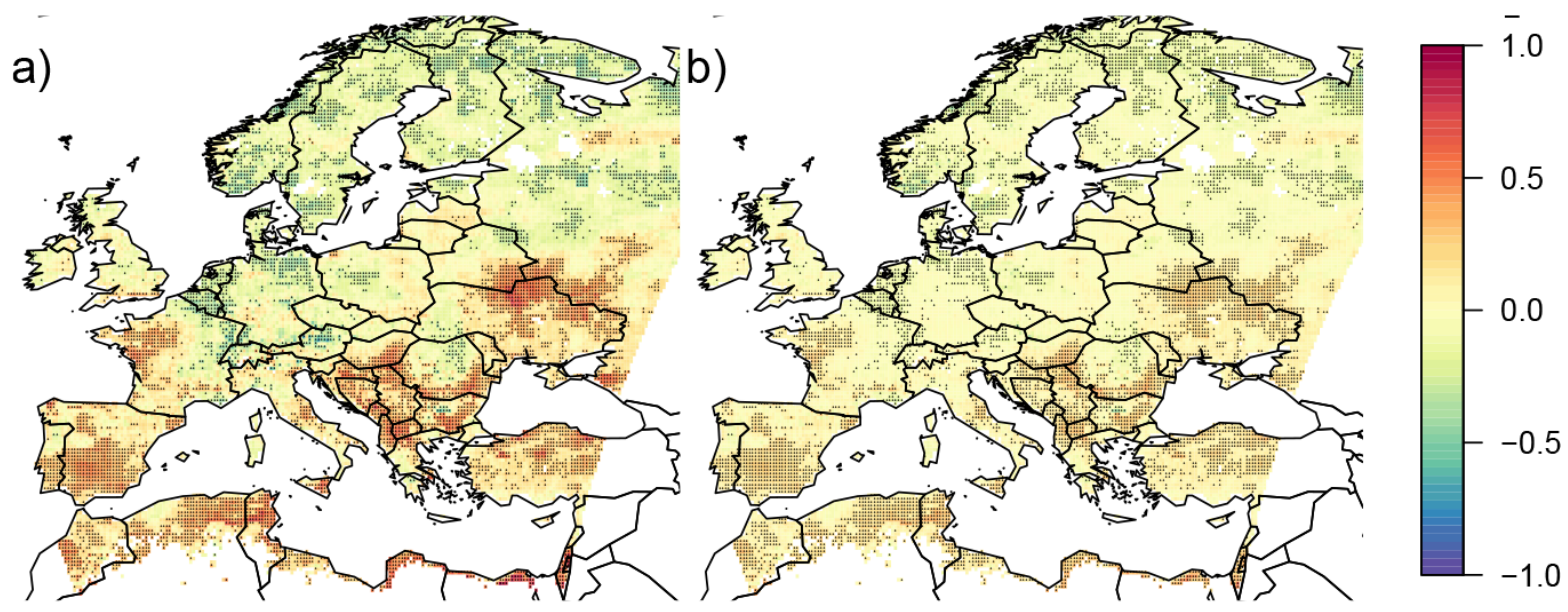

Figure 4. Ecosystem vulnerability (a) and risk (b) of carbon losses (negative NBP) to SPEI for the period 1981 to 2010. Reddish colours indicate high vulnerability to drought; significant cells are marked with black dots.

combined or single, immediate or lagged, direct or indirect effects of weather extremes on ecosystem condition into one metric (following the concept of Frank et al. (accepted)).

For the perception of the ecosystem hazard it is important to choose a system variable sys that represents vulnerability of an ecosystem (e.g. high respiration or low net primary productivity). But also the associated threshold for the definition of the hazard has to be selected with care (e.g. NPP $<0$ ). One option is to choose a variable for the hazard definition that is widely accepted and easy to interpret for the ecosystem under consideration. Both choices, sys and the threshold, should be made with respect to the goal of the study. Here, we selected carbon release to the atmosphere as the hazard, i.e. negative net biome production (NBP). This variable is commonly used to interpret carbon fluxes of an ecosystem as net emitter through respiration and disturbances or net accumulator through photosynthesis (Schulze, 2006).

With an ecosystem in equilibrium, emissions equal gains more or less so that short-term carbon releases do not represent a hazard to the ecosystem. For ecosystems in transition, only longer lasting net losses may pose a problem and are thus suitable for defining hazard. In order to eliminate the seasonal cycle and thus short-term fluctuations, we take NBP sums over 12 months (Eq. 5). This identifies situations where on an annual timescale net carbon losses of an ecosystem to the atmosphere have been larger than net gains. And it avoids the unwanted detection of vulnerability in regions of regular seasonal drought where ecosystems are adapted and usually compensate carbon losses during the vegetation period or rainy season. Thus, the chosen time window of 12 months is not related to the life expectancy of the vegetation or the expected duration of droughts.

An extension of the approach would be the application to measured data. Nevertheless, scarce data availability for larger areas (regional to continental scale) is a drawback.
Eddy covariance data for single sites seem to be suitable but are seldom available for more than 20 years to provide sufficient data points for probability distributions. Data products on the continental scale would be beneficial and attractive but not yet existing (Jung et al., 2011). So far, the application of our concept reveals the reaction of the model LPJmL to climatic conditions which represent our condensed knowledge about plant processes. Specifically LPJmL is validated thoroughly for each of its components, the calculation of vulnerability measures from model results on the European scale provides an important and informative but nevertheless first step in this context.

With the proposed concept, ecosystem vulnerability can be integrated into the framework proposed by Ionescu et al. (2009). For them, three main functions have to be fulfilled. First, there has to be an entity that is vulnerable, which in our case is the property of an ecosystem to be a source or a sink for carbon. Secondly, a stimulus has to exist to which the entity is vulnerable, which here is exerted by the climatic variables. Thirdly, the interaction of entity and stimulus has to have a notion of worse or better which is given by assigning a hazard to an ecosystem when it is a carbon source. The perception of Ionescu et al. (2009) of the risk also matches well to formula Eq. (3), since they define risk as vulnerability weighted by the occurrence of the hazard. We go one step further in that we cannot only distinguish between vulnerable and non-vulnerable conditions, but quantify it along a continuum. This opens new ways to interpret ecosystem vulnerability in the context of gradual ecological changes and system behaviour with respect to biogeochemical cycles.

\subsection{Context of ecosystem vulnerability}

Our concept quantifies the long-term and combined impact of extreme weather events, and does not evaluate the effects of single events. By assigning each monthly value of sys 

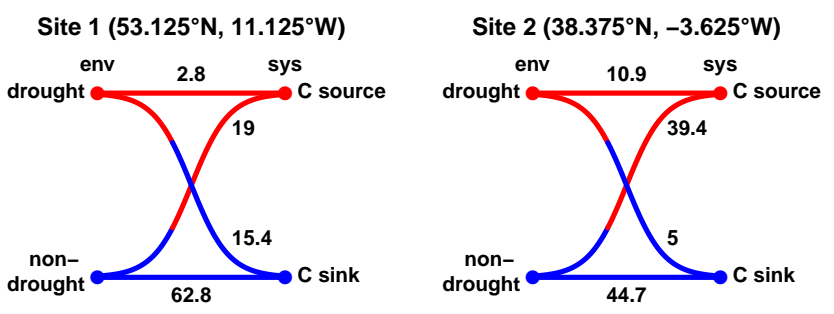

Figure 5. Probabilities (in percent) after Smith (2011) for all four combinations of non-hazardous and hazardous env with hazardous and non-hazardous sys conditions. Data are the same as in Fig. 2 for site 1 in Germany and site 2 in Spain for the period 1981-2010.

to either the hazard or the non-hazard group, each individual ecosystem behaviour contributes to the assessment of our long-term ecosystem vulnerability and risk.

It links to Smith (2011) by directly addressing the behaviour of ecosystems and relating it to the meteorological conditions under which it occurs. Exploring the connection between hazards and extremes (sensu Smith, 2011), both concepts define thresholds for hazardous or extreme conditions and both examine the physical and biological spheres independently. In contrast to Smith (2011), we apply not a distributional threshold (referring to extremeness) but a qualitative threshold (i.e. ecosystem as a source or sink of carbon). Applying the same logic to the environmental driver env (e.g. like Van Oijen et al., 2013), a meaningful threshold can be set for the environmental variable SPEI of -1 (as defined for drought in Vicente-Serrano et al., 2010). This allows probabilities to be derived also for the transition of non-hazardous env events into hazardous and non-hazardous sys conditions. Following Smith (2011), it is then possible to quantify the probability of occurrence of all four combinations of the ecosystem variable sys, in our case NBP, and the environmental variable env, here SPEI (Fig. 5).

We quantified all four combinations for two sites (see Fig. 2) using the simulated 30-year time series (as described in Sect. 2). At both sites, hazardous env conditions occur in $16 \%$ of the months but the responses of the ecosystems differ. At site 1 , for which $V_{\mathrm{E}}$ is negative, about $22 \%$ of the $e n v$ data belong to the hazard group and less than $3 \%$ of the data link hazardous sys conditions with hazardous env conditions (Fig. 5 left). At site 2 with positive $V_{\mathrm{E}}$, about $50 \%$ of the env time series belong to the hazard group and in about $11 \%$ of the months, hazardous env conditions coincide with hazardous sys conditions (Fig. 5 right). Under current climate conditions, the Mediterranean site experiences more hazardous (extreme) environmental condition that lead to carbon release.

This shows how the proposed PRA takes up the concern of Smith (2011) to include the ecosystem perspective into data driven probabilistic risk assessment. This way, we are able to back-up the theoretical concept of Smith (2011) with data at the continental scale.

\subsection{Interpretation of ecosystem vulnerability values}

The quantification of ecosystem vulnerability and risk requires some careful interpretation of the obtained values. First of all, their units are defined by the chosen env and, secondly, the interpretation of their sign and magnitude depend on our interpretation of the damaging effect of env. Therefore, we give both some consideration.

High values of ecosystem vulnerability indicate high vulnerability to lose carbon due to drier conditions than usual, i.e. the SPEI difference during ecosystem hazards is decisive for the vulnerability and not the absolute values of the drought indicator. This difference reflects the distance between two average conditions: (a) advantageous climatic conditions under which the ecosystem accumulates carbon and, (b) unfavourable climatic conditions under which the defined hazard is occurring and the ecosystem emits carbon to the atmosphere. Thus, the higher the difference and therefore $V_{\mathrm{E}}$, the higher the distance between favourable meteorological conditions (non-hazard) and those leading to the ecosystem hazard. Hence, high $V_{\mathrm{E}}$ values express the difference between environmental conditions to which the ecosystem is adapted and those conditions under which the ecosystem emits carbon. An increase in $V_{\mathrm{E}}$ in the future can have two reasons: conditions are dry more often (low SPEI values) or become more extreme (extremely low SPEI values). The latter also means that weather extremes, in our case droughts, are causing hazardous conditions more often which result in lower mean values in the hazard group. Hence, the difference between the hazard and non-hazard groups increases.

The approach does not specifically allow the impact of single events to be identified but the long-term and general occurrence of hazardous events, either being more severe, frequent or lasting longer and more importantly impact these changes have on ecosystem status, which is interesting from an ecological and management point of view. Extremes events, such as droughts causing negative NBP, have been identified for past weather extremes (Ciais et al., 2005; Reichstein et al., 2007). Such events, which occur during the investigated 30-year period and lead to vulnerable conditions for the ecosystem's carbon balance, fall into the hazard subset of data points. It is possible to identify the position of these hazard samples in the scatterplot (Fig. 2) and estimate the severity of the corresponding extreme event. However, the presented ecosystem vulnerability approach evaluates long-term effects that these weather extremes have on the affected ecosystem. It looks not only at short-term impacts, which occur immediately after the event, but captures long-term effects determining the capacity of the ecosystem to recover and stabilize. This is an important point as it refers to the ecosystem's resilience.

Areas with ecosystem vulnerability values close to zero are those with similar mean env values in the hazard and nonhazard group. Thus, ecosystems are not or only marginally vulnerable to $e n v$, in our case drought. The proximity be- 
tween both average values suggests that within the considered period any potential causal relationship between sys and $e n v$ (in our case droughts causing negative NBP) did not materialize. The marginality of the impact of $e n v$ was additionally evaluated by considering the statistical significance of the difference between hazard and non-hazard group.

Negative ecosystem vulnerability indicates that the ecosystem is vulnerable (carbon losses do occur) but either not to the anticipated data range of env (low or high values) or not to the specified env. In the first situation, drought is not responsible for the ecosystem's carbon loss. Here, the expected value of SPEI for negative NBP (i.e. a hazard) is higher than that for positive NBP, i.e. under non-hazard conditions. In the second situation, other environmental variables, e.g. $P$ or $T$, should be considered and evaluated for their potential impact on the ecosystem. Since $V_{\mathrm{E}}$ is based on a probabilistic approach, its values only indicate potential causalities which have to be evaluated subsequently.

There are two possibilities of failing $V_{\mathrm{E}}$ determination: when the hazard does not occur at all in the study period, i.e. there is no vulnerability, or when there is no data point in the non-hazard group. The latter case can arise when due to changing environmental conditions each data point falls into the hazard group. In order not to misinterpret missing $V_{\mathrm{E}}$ values, the reason for the calculation failure should be reported. However, the ecological interpretation for the latter case is simple: the ecosystem has converted into a continuous carbon source and might undergo rapid and profound transitions to a new ecosystem state.

An interpretation of $R_{\mathrm{E}}$ values may reflect on the sign of the calculated value, i.e. whether a damaging effect of the regarded env can be stated, and on the likelihood of the quantified vulnerability. The ecosystem vulnerability approach quantifies weather conditions that caused ecosystems to become a source of carbon to the atmosphere. The risk can be lower than the vulnerability when hazardous events occur less often, i.e. the full vulnerability potential was not utilized. Similar to other metric or model concepts, the presented approach reflects the impacts of currently known ecosystem hazards. For hazards emerging in the future, the ecosystem vulnerability approach can be adjusted accordingly.

\subsection{European pattern of ecosystem vulnerability}

Under current climatic conditions, $V_{\mathrm{E}}$ and $R_{\mathrm{E}}$ values can be calculated at the European scale because hazard occurrence in the LPJmL results is sufficiently frequent. Ecosystems in southern Europe, i.e. in the Mediterranean basin, and even more so on the Balkan peninsula, in Turkey and the Ukraine, are known to experience severe drought stress (Bussotti and Ferretti, 1998; Piovesan et al., 2008; Anav and Mariotti, 2011). The highest $V_{\mathrm{E}}$ values, though, were calculated for eastern Europe for current conditions. Already today, ecosystems in these regions lack sufficient water to compensate for drought stress in order to avoid carbon loss and fire ignition.
Here, increasing attention is directed to the evaluation of carbon emissions to the atmosphere by fires (Ulevicius et al., 2010; Barnaba et al., 2011). Zscheischler et al. (2014a) found most carbon losses in recent observational data on gross primary production (GPP) to be caused by drought and fire. It is noteworthy as they could attribute the majority of carbon loss to few and extreme situations.

Temperate regions in central and eastern Europe as well as boreal regions in northern Europe show vulnerability values against drought close to zero, most of which are not significant. In these ecosystems, the hazard occurrence is rare and the difference between hazardous and non-hazardous conditions is small. Here, the few periods during which carbon is emitted to the atmosphere are balanced by periods of carbon uptake so that the affected ecosystems are not vulnerable to drought under current climate.

For northern Europe, negative vulnerability values were calculated for boreal forests as well as tundra ecosystems. Belgium, the Netherlands, northern Germany and large areas in Scandinavia fall into this category (Fig. 2a, Fig. 4a and appendix A). In these regions, moisture supply is higher than needed. When carbon loss is observed here, vegetation growth is limited by factors other than drought. These could be caused either by unfavourable temperature or radiation conditions or an excess supply of water (see examples in appendix B). Using phyloclimatic plasticity functions, Garcia-Lopez and Allue (2012) conclude that forests in Scandinavia will benefit from decreasing precipitation and increasing temperature.

We found the corresponding risk to be negligible under current conditions. Even for the Mediterranean, water scarcity as expressed with $R_{\mathrm{E}}$ values for SPEI (Fig. 4b) and precipitation (Fig. A1b) occurs rarely so that the significant $V_{\mathrm{E}}$ values are reduced.

Although the analysis is undertaken with model results solely, especially the responses of LPJmL to weather extremes are well validated. For the European heatwave of 2003, Reichstein et al. (2007) compared model results for GPP to remote sensing products and found a standard deviation between model results and data of less than $25 \mathrm{gC} \mathrm{m}^{-2}$ month $^{-1}$ for the majority of the grid cells. Zscheischler et al. (2014b) investigated extremes in GPP at the global scale and found LPJmL to be well able to reproduce the extent and impact of extreme events. Considering the role of fire for $V_{\mathrm{E}}$ values in southern Europe, an in-depth evaluation of the fire model is in progress using data from the GFED database (Giglio et al., 2010; van der Werf et al., 2010) and the EFFIS database (EFFIS, 2014) for a joint analysis of vegetation-fire models. 


\section{Conclusions}

From our ecosystem vulnerability and risk assessment, four main conclusions can be derived:

1. The quantification of ecosystem vulnerability by a probability-based concept allows identification of weather conditions that coincide with hazardous ecosystem responses.

2. Drought is a major threat to European ecosystems under current conditions especially in southern Europe.

3. In ecosystems in northern Europe, hazards in the biosphere occur but they are not related to water shortage or surplus.

4. About one-fifth of the European area is vulnerable to drought.
We can subsume ecosystem responses to climate variability that have a long-term effect and put its carbon storage at risk. This can be regarded as an indicator for ecosystem vulnerability. Whereas Van Oijen et al. (2013) pre-define weather conditions that form a hazard for the ecosystem, our ecosystem vulnerability approach quantifies those hazardous conditions when the ecosystem is losing carbon over a long time (the subsequent 12 months). We quantify those hazardous conditions where climate and weather extremes lead to an extreme, yet hazardous response. By comparing different climate variables leading to hazardous conditions in the ecosystem, their relative importance to the overall vulnerability of the ecosystem can be quantified. Additionally, the approach allows us to identify when and where the environmental driver under investigation was not responsible for the ecosystem response. This opens a new perspective for comparing the climate perspective of Van Oijen et al. (2013) against the ecosystem perspective to evaluate where both approaches identify climate conditions leading to an extreme response in the ecosystem. It also allows for future investigation of climate change and the contribution of climate variability to changing ecosystem vulnerability. 
Appendix A: Ecosystem vulnerability and risk to additional $e n v$ variables

In order to derive a more comprehensive analysis of the hazard occurrence in terrestrial ecosystems, also other environmental variables were considered. Apart from $S$ as monthly values of the Standardized Precipitation Evapotranspiration Index SPEI (-), $P$ as monthly precipitation $\left(\mathrm{mm} \mathrm{month}{ }^{-1}\right.$ ), $T$ as monthly mean temperature $\left({ }^{\circ} \mathrm{C}\right)$, and $C$ as monthly values of CDDs (consecutive dry days in days) with precipitation below $1 \mathrm{~mm}$ (described in Sect. 3.1). Each meteorological variable chosen for env has a specific range where it negatively influences the ecosystem variable sys. For $T$ and $C$, high values are expected to be problematic, whereas for $P$ and $S$, hazardous conditions of sys are expected at low values. Since the impact of these variables are qualitatively different, we need to define a conversion factor $\delta$ (Eq. A1)

$\delta=\left\{\begin{aligned} 1: & \text { hazard expectance at low values of env } \\ -1: & \text { hazard expectance at high values of env }\end{aligned}\right.$

to re-scale the calculated $V_{\mathrm{E}}$ (Eq. 1) such that positive values always mean vulnerable conditions and calculated $V_{\mathrm{E}}$ from several $e n v$ can be compared with each other. In our case, we define $\delta=1$ for $S$ and $P$, and $\delta=-1$ for $T$ and $C$.

Spatial distributions of ecosystem vulnerability and risk to water shortage ( $P$ and $C$ ) (Figs. A1 and A2) reveal similar patterns as to $S$ (compare Fig. 4), but not to $T$ (Fig. A3). Ecosystem vulnerability to precipitation (Fig. A1a) map the Mediterranean, the Balkans, eastern Ukraine and part of southern Russia with $V_{\mathrm{E}}$ values of more than $10 \mathrm{~mm} \mathrm{month}^{-1}$. For these regions, the risk to drought is approximately $5 \mathrm{~mm} \mathrm{month}^{-1}$ (Fig. A1b). For southern and eastern Norway as well as the mountainous regions of France, Belgium and Switzerland, $V_{\mathrm{E}}$ is mostly negative (below $-10 \mathrm{~mm} \mathrm{month}^{-1}$ ), i.e. not vulnerable to lower precipitation. Due to the rare hazard occurrence, $R_{\mathrm{E}}$ reaches values below $-10 \mathrm{~mm} \mathrm{month}^{-1}$ only in marginal areas in southern Norway. Areas that are vulnerable to low precipitation have also significant $V_{\mathrm{E}}$ values for consecutive dry days (Fig. A2a). Hazard occurrence there is connected to more than 4 additional days without precipitation. Ecosystem vulnerability to temperature ( $T$, Fig. A3a) is mostly positive but only rarely exceeds $1 \mathrm{~K}$. The corresponding risk (Fig. A3b) is between 0.5 and $1 \mathrm{~K}$ and does not show a clear spatial pattern.

Combining the results for $V_{\mathrm{E}}$ for all $e n v$ considered, we can assess areas in which the occurrence of the defined hazard can be connected to environmental drivers. For $55.3 \%$ of the European area, at least one of the env variables leads to significant $V_{\mathrm{E}}$ values. Positive $V_{\mathrm{E}}$ values that are significant are determined at $28 \%$ of the area, negative $V_{\mathrm{E}}$ at $29 \%$. At $13 \%$ of the area, positive $V_{\mathrm{E}}$ to two different env variables are calculated and at $3.3 \%$ even for 3 of the env. The latter holds for parts of inner Turkey, southern Iberian Peninsula, Greece and the Balkans. At $13.8 \%$ of the area, negative $V_{\mathrm{E}}$ to
Table A1. Ecosystem vulnerability $V_{\mathrm{E}}$ and risk $R_{\mathrm{E}}$ (mean value \pm standard deviation) and percentage of affected area $(\%)$ in the SREX regions (Table 1$)$ of yearly carbon loss $(\mathrm{NBP}<0)$ to the $e n v$ variables SPEI $S(-)$, precipitation $P\left(\mathrm{~mm} \mathrm{month}^{-1}\right)$, temperature

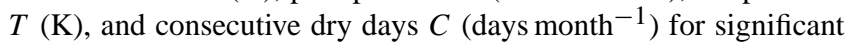
cells. Bold numbers denote high positive values (mean value $>$ standard deviation).

\begin{tabular}{lcccr}
\hline Region & env & $V_{\mathrm{E}}$ & $R_{\mathrm{E}}$ & area affected \\
\hline EU & $S$ & $0.1 \pm 0.3$ & $0.08 \pm 0.17$ & 21.5 \\
NEU & $S$ & $-0.3 \pm 0.1$ & $-0.14 \pm 0.07$ & 1.0 \\
CEU & $S$ & $0.1 \pm 0.3$ & $0.07 \pm 0.14$ & 20.1 \\
MED & $S$ & $\mathbf{0 . 3} \pm 0.2$ & $\mathbf{0 . 1 7} \pm 0.09$ & 52.7 \\
\hline EU & $P$ & $-2.1 \pm 10.4$ & $-2.11 \pm 5.32$ & 14.8 \\
NEU & $P$ & $-9.4 \pm 4.8$ & $-4.75 \pm 4.10$ & 0.0 \\
CEU & $P$ & $-3.6 \pm 10.2$ & $-0.55 \pm 4.00$ & 10.5 \\
MED & $P$ & $\mathbf{9 . 7} \pm 5.3$ & $\mathbf{4 . 8 7} \pm 2.51$ & 40.4 \\
\hline EU & $T$ & $0.8 \pm 1.9$ & $0.78 \pm 0.77$ & 1.5 \\
NEU & $T$ & $1.0 \pm 1.7$ & $0.25 \pm 0.76$ & 1.7 \\
CEU & $T$ & $0.3 \pm 2.2$ & $0.35 \pm 0.76$ & 1.2 \\
MED & $T$ & $1.1 \pm 1.5$ & $0.49 \pm 0.77$ & 2.0 \\
\hline EU & $C$ & $1.1 \pm 6.4$ & $1.13 \pm 3.81$ & 6.0 \\
NEU & $C$ & $-1.3 \pm 0.3$ & $-0.64 \pm 0.24$ & 0.0 \\
CEU & $C$ & $0.4 \pm 1.8$ & $0.32 \pm 0.77$ & 3.5 \\
MED & $C$ & $4.8 \pm 10.1$ & $2.63 \pm 6.17$ & 16.1 \\
\hline
\end{tabular}

two different env are determined and at $3.4 \%$ even for 3 env variables. This occurs in northern Scandinavia and the Baltic states. It has to be stated that for $44.7 \%$ of the area none of the considered env resulted in a significant $V_{\mathrm{E}}$ value. For these areas, the occurrence of the hazard is not attributable to an environmental driver so far.

When comparing zonal averages of $V_{\mathrm{E}}$ according to the SREX regions (Table 1), ecosystem vulnerability is most consistent for the Mediterranean region MED to water shortage (Table A1). Positive $V_{\mathrm{E}}$ and $R_{\mathrm{E}}$ values in MED were calculated to drought ( $S$ and $P$ ) for the majority of grid cells with a significant difference between the hazard and nonhazard groups. For this region, $V_{\mathrm{E}}$ mean values are positive for all env considered. Since higher precipitation and lower temperatures (resulting in lower SPEI values) may coincide with lower radiation, it is reasonable to evaluate negative $V_{\mathrm{E}}$ to $S$. This is the case in eastern France, northern Germany, Estonia and northern Sweden.

The reaction of the LPJmL model to temperature seems to be different to that on water related processes. Here, the pattern of $V_{\mathrm{E}}$ and $R_{\mathrm{E}}$ values is less coherent than for $S, P$ or $C$. This has to be kept in mind when interpreting the results presented here. Although LPJmL is validated thoroughly for the process behaviour on various spatial and temporal scales, the ecosystem vulnerability and risk determination reflect the model performance and its ability to capture ecosystem responses to environmental drivers. 

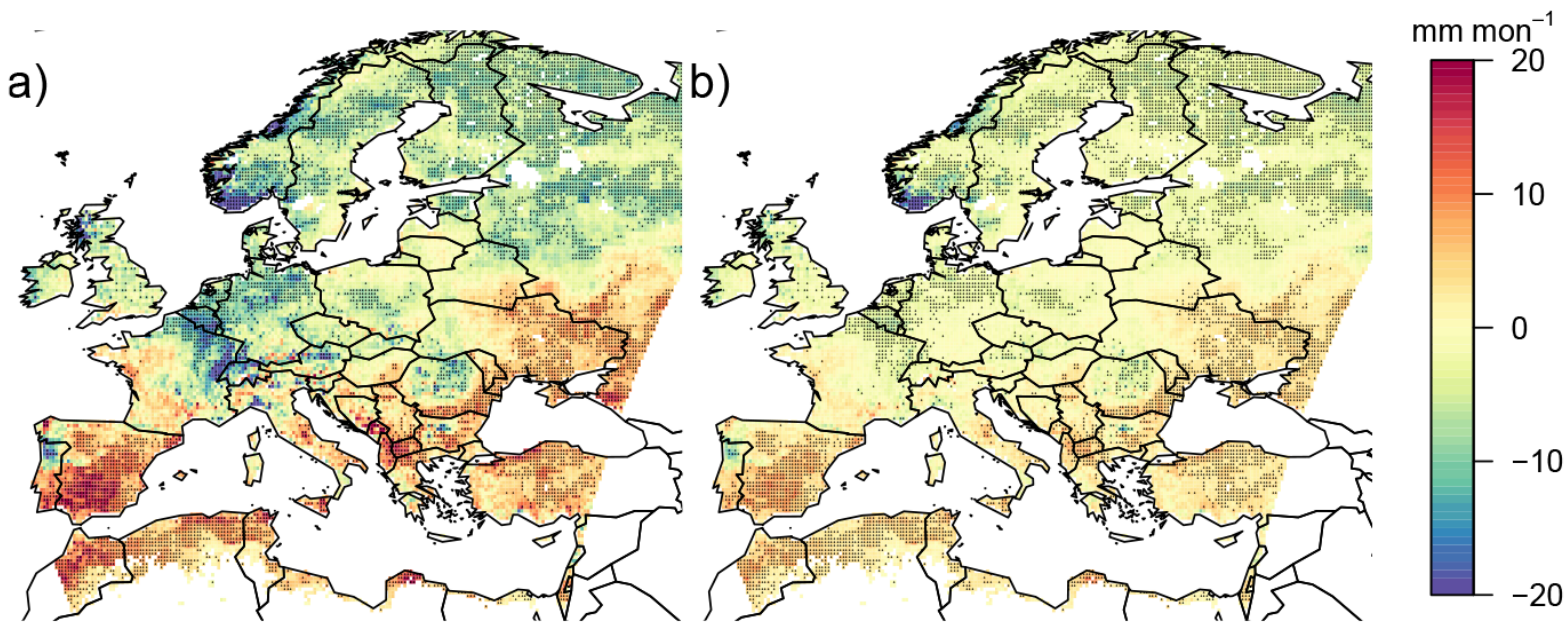

Figure A1. Ecosystem vulnerability (a) and risk (b) of carbon losses (negative NBP) to $P$ for the period 1981 to 2010 . Reddish colours indicate high vulnerability to water shortage; significant cells are marked with black dots.
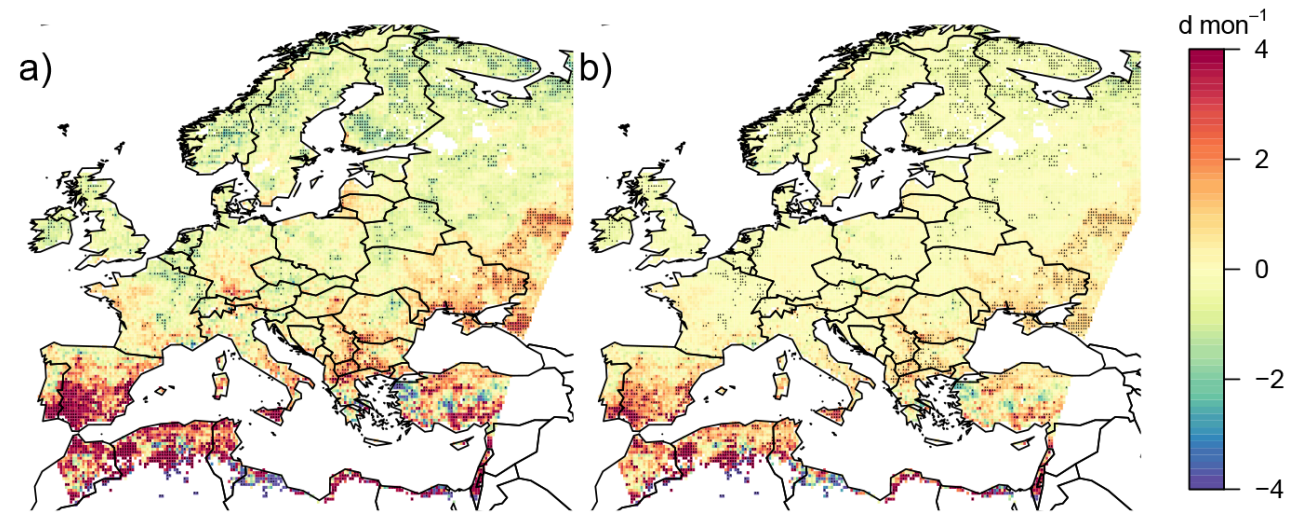

Figure A2. Ecosystem vulnerability (a) and risk (b) of carbon losses (negative NBP) to $C$ for the period 1981 to 2010. Reddish colours indicate high vulnerability to drought periods; significant cells are marked with black dots.

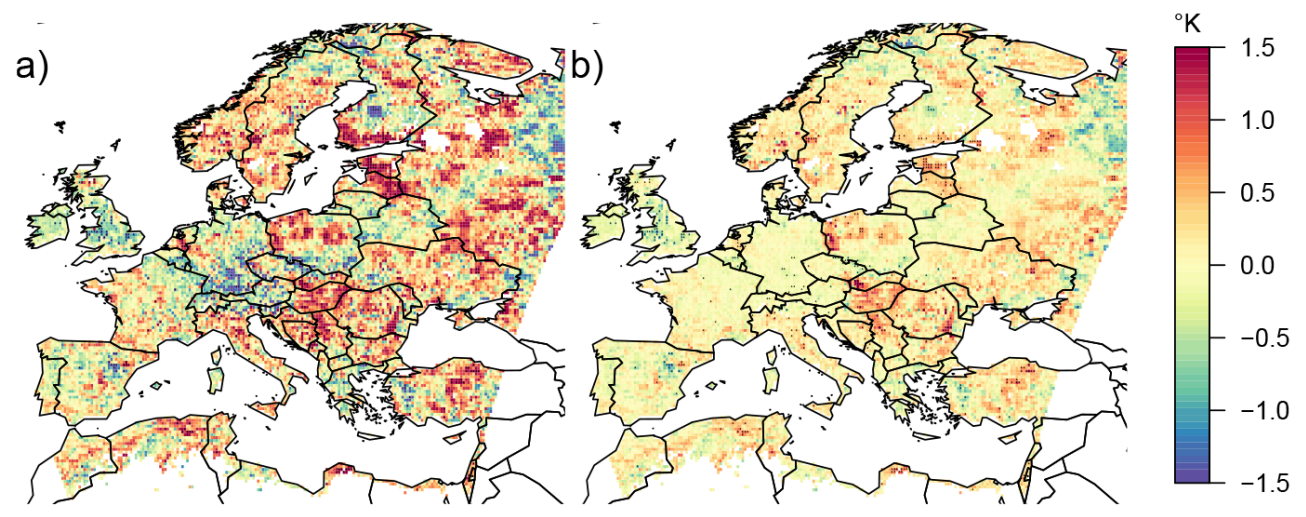

Figure A3. Ecosystem vulnerability (a) and risk (b) of carbon losses (negative NBP) to $T$ for the period 1981 to 2010 . Reddish colours indicate high vulnerability to heat stress; significant cells are marked with black dots. 


\section{Appendix B: Components of carbon fluxes}

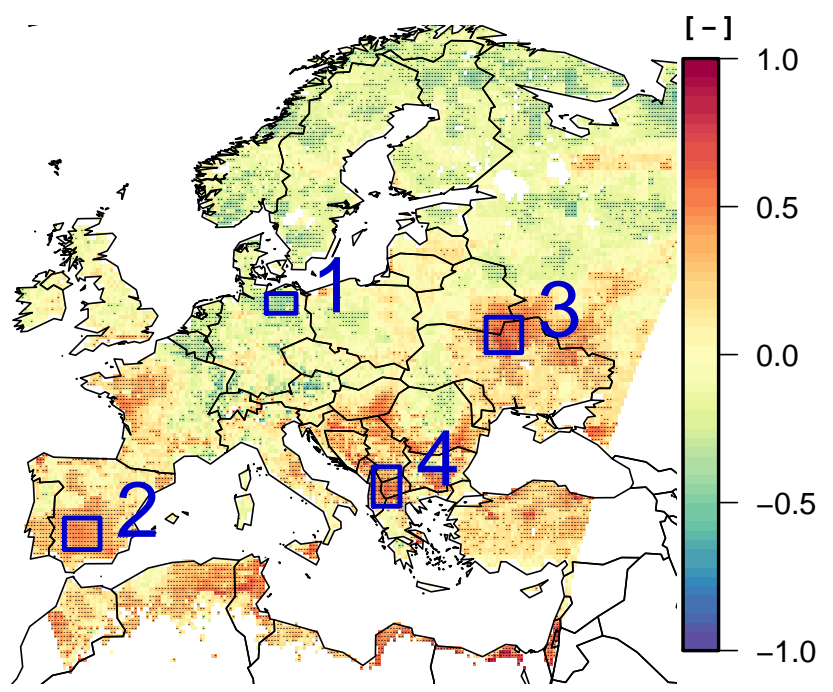

Figure B1. Ecosystem vulnerability to $S$ as in Fig. 4a with marked areas 1 to 4, for which components of carbon fluxes in hazard and non-hazard group are shown.

Underlying mechanisms leading to significant positive (and negative) $V_{\mathrm{E}}$ values to $S$ are examined more closely for 4 regions depicted in Fig. B1. For these regions, the components of the carbon flux NBP are depicted and discussed for the hazard and non-hazard groups of data.

Area 1: Natural vegetation in northern Germany consists mostly of temperate trees $(50 \%$ needle leaved evergreens like pine, $33 \%$ broadleaved summer greens like beech and oak) with a minor contribution of grass vegetation (16\%). In situations with negative NBP (Fig. B2a), the weather is rainier and shady (higher precipitation and lower radiation, see Fig. B2f, h) whereas the temperature does not differ between hazard and non-hazard groups. The rather low radiation reduces NPP (Fig. B2b) given the fact that photosynthesis is also radiation-driven and vegetation growth. Both, the increase in soil moisture and an increase in the litter pool enhance soil respiration (Fig. B2c) and contribute to the loss of carbon from the biosphere.

Area 2: Natural vegetation in southern Spain is dominated by grasses $(68 \%)$ and temperate evergreen trees $(15 \%$ needle leaved such as pine, $11 \%$ broadleaved such as Quercus ilex). In situations with negative NBP (Fig. B3a), precipitation is low $\left(<40 \mathrm{~mm} \mathrm{month}^{-1}\right)$ (Fig. B3f), leading to a fast turnover of NPP into litter and an increase in fire occurrence (Fig. B3d). NPP is substantially reduced in the hazard case (Fig. B3b) and biomass burnt substantially increased (Fig. B3d). Heterotrophic respiration, Rh, is slightly reduced (Fig. B3c) since soil moisture is not sufficient and the existing litter is reduced by fire. This represents Mediterranean vegetation which is regularly subject to drought.
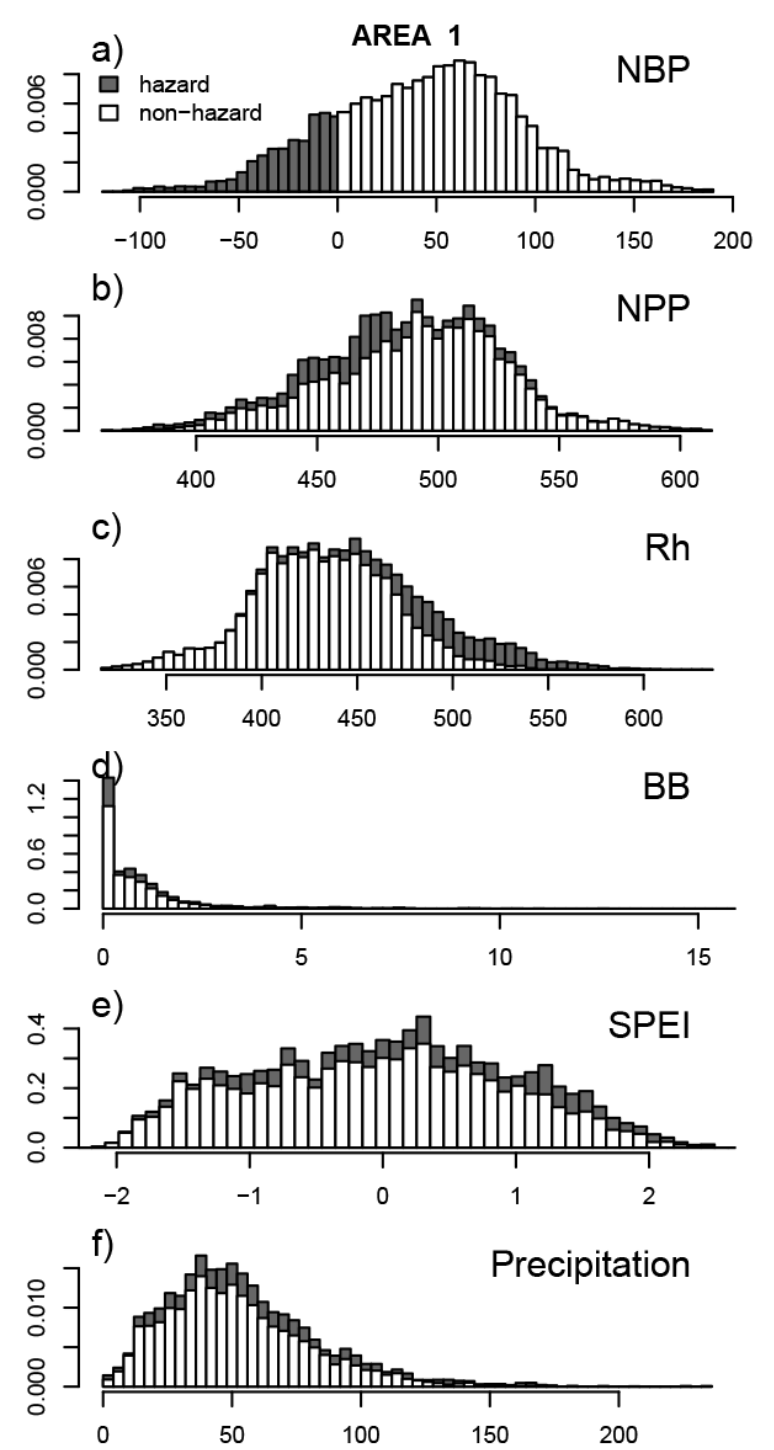

g)
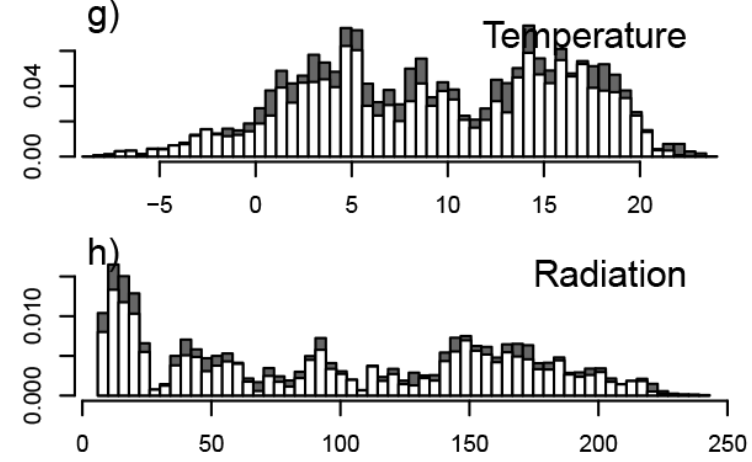

Figure B2. Probability distributions for area 1 (see Fig. B1) of (a) NBP and its contributions (b) NPP, (c) Rh, and (d) BB (all in $\mathrm{gC} \mathrm{m}^{-2} \mathrm{a}^{-1}$ ) as well as monthly values for (e) SPEI (dimensionless), (f) precipitation $\left(\mathrm{mm} \mathrm{month}^{-1}\right),(\mathbf{g})$ temperature $\left({ }^{\circ} \mathrm{C}\right)$ and (h) short-wave downward radiation $\left(\mathrm{W} \mathrm{m}^{-2}\right)$. Dark shading denotes values in the hazard group, white shading in the non-hazard group. 

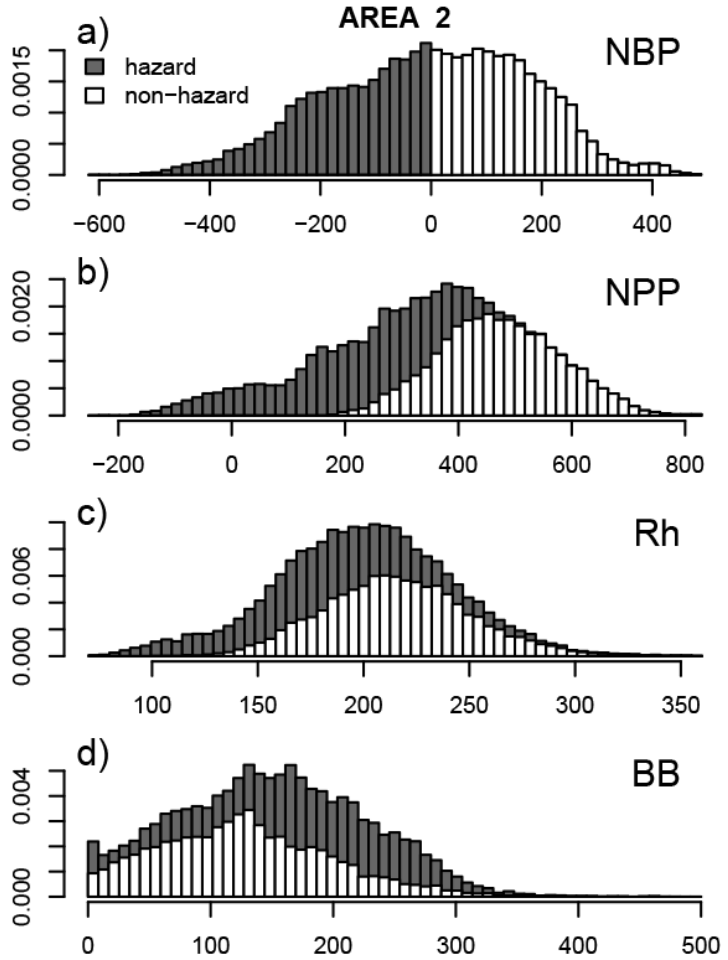

e)
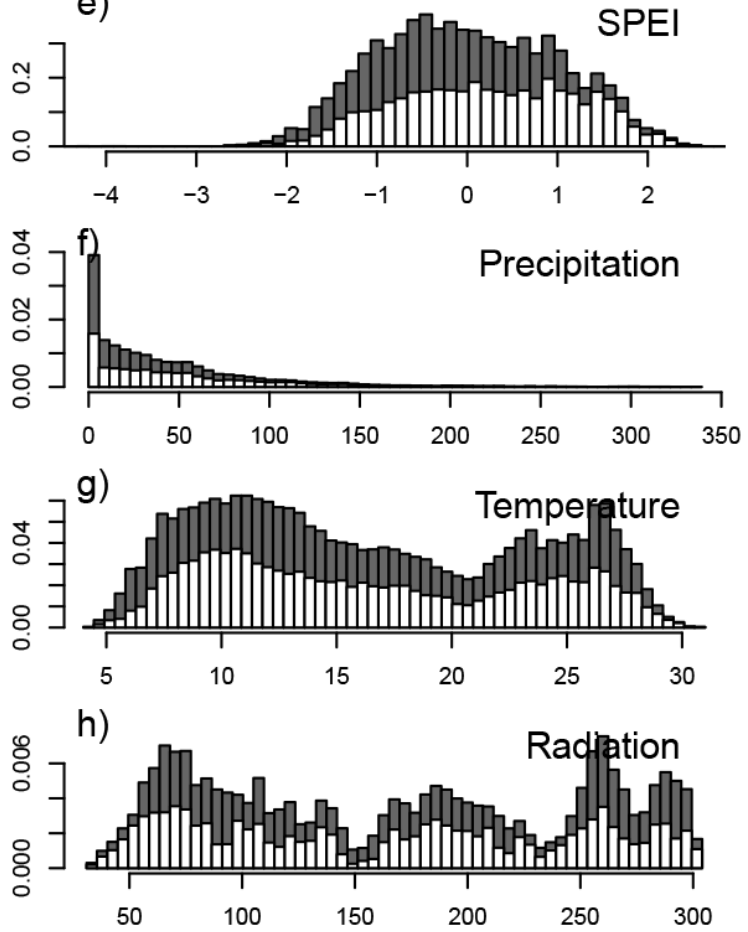

Figure B3. Probability distributions for area 2 (see Fig. B1) of (a) NBP and its contributions (b) NPP, (c) Rh, and (d) BB (all in $\mathrm{gC} \mathrm{m}^{-2} \mathrm{a}^{-1}$ ) as well as monthly values for (e) SPEI (dimensionless), (f) precipitation $\left(\mathrm{mm}\right.$ month $\left.^{-1}\right),(\mathrm{g})$ temperature $\left({ }^{\circ} \mathrm{C}\right)$ and (h) short-wave downward radiation $\left(\mathrm{W} \mathrm{m}^{-2}\right)$. Dark shading denotes values in the hazard group, white shading in the non-hazard group.
Area 3: In the border region of Ukraine, Belarus and Russia, the forest area is covered by boreal needle leaved evergreen trees (35\%, pines) and broadleaved summer green trees (29\% temperate trees like beech and oak, $24 \%$ boreal species like birch, poplar or aspen) and with a minor grass component $(12 \%)$. In the hazard case, precipitation is reduced and temperature elevated in comparison to the nonhazard case (see Fig. B4f, g) but the range of values are not representing drought conditions. Soil moisture is sufficient to support heterotrophic respiration (increased values for the hazard group, Fig. B4c). Fires are occurring frequently but with very low carbon emissions (low biomass burnt, Fig. B4d). The slight decrease of NPP (Fig. B4b) is associated with a loss of vegetation carbon under frequent hazard occurrence. The ecosystems is this region are affected by water shortage and drought stress.

Area 4: Vegetation in the mountainous region in Macedonia and Albania consists mostly of temperate trees (29\% needle leaved evergreen trees like pine, $26 \%$ broadleaved summer green trees like beech or oak) and to a lesser portion of boreal trees ( $15 \%$ needle leaved evergreen trees like spruce, $8 \%$ broadleaved summer green trees like birch, poplar or aspen). Grassy vegetation is simulated for $22 \%$ of the area. The heterogeneity of the vegetation composition is accompanied by very variable weather conditions (Fig. B5e to h). Hazard conditions for the biosphere differ mainly in precipitation amounts which are reduced in comparison to the non-hazard group. When NBP is negative in this area (Fig. B5a), NPP is low (Fig. B5b) and heterotrophic respiration is slightly lower (Fig. B5c). Lower NPP is associated with a reduction in tree growth (the increment of the vegetation carbon is negatively correlated with the hazard occurrence, data not shown). So even relatively high carbon fluxes under hazard conditions (NPP between 300 and $600 \mathrm{gC} \mathrm{m}^{-2} \mathrm{a}^{-1}$ ) cannot be accumulated in the vegetation because soil respiration is enhanced and the assimilated carbon is decomposed quickly. The frequently occurring fires with moderate intensity between 5 and $50 \mathrm{gC} \mathrm{m}^{-2} \mathrm{a}^{-1}$ are determined in this area in 4 months per year on average. Fires with higher carbon fluxes are more seldom (in one month per year on average) but disturb the ecosystems severely enough to prevent carbon accumulation. 

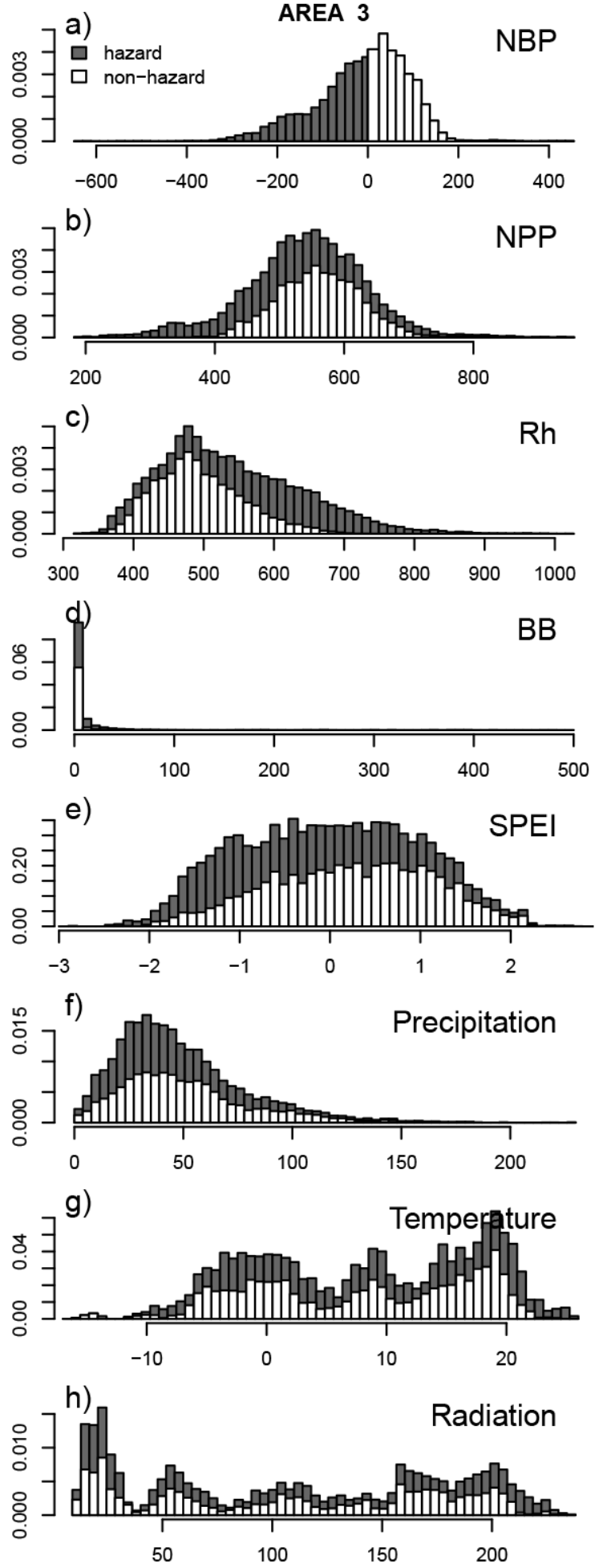

Figure B4. Probability distributions for area 3 (see Fig. B1) of (a) NBP and its contributions (b) NPP, (c) Rh, and (d) BB (all in $\mathrm{gC} \mathrm{m}^{-2} \mathrm{a}^{-1}$ ) as well as monthly values for (e) SPEI (dimensionless), (f) precipitation $\left(\mathrm{mm} \mathrm{month}^{-1}\right),(\mathrm{g})$ temperature $\left({ }^{\circ} \mathrm{C}\right)$ and (h) short-wave downward radiation $\left(\mathrm{W} \mathrm{m}^{-2}\right)$. Dark shading denotes values in the hazard group, white shading in the non-hazard group.
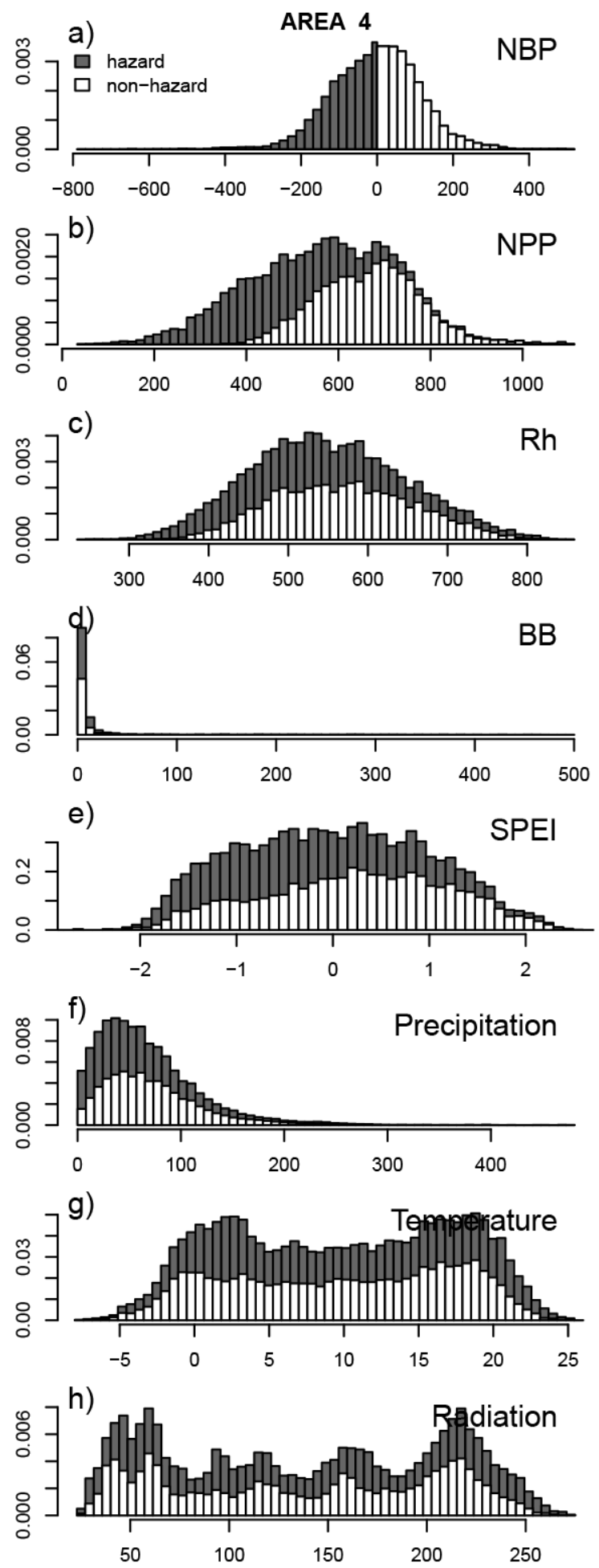

Figure B5. Probability distributions for area 4 (see Fig. B1) of (a) NBP and its contributions (b) NPP, (c) Rh, and (d) BB (all in $\mathrm{gC} \mathrm{m}^{-2} \mathrm{a}^{-1}$ ) as well as monthly values for (e) SPEI (dimensionless), (f) precipitation $\left(\mathrm{mm} \mathrm{month}^{-1}\right),(\mathrm{g})$ temperature $\left({ }^{\circ} \mathrm{C}\right)$ and (h) short-wave downward radiation $\left(\mathrm{W} \mathrm{m}^{-2}\right)$. Dark shading denotes values in the hazard group, white shading in the non-hazard group. 
Acknowledgements. We thank Christian Beer, Ulrich Weber and Enrico Tomelleri from MPI-BGC Jena for processing the climate data set in the framework of the CARBO-Extreme project FP7/226701. S. Rolinski, A. Rammig and A. Walz were partly funded by the CARBO-Extreme project FP7/226701. S. Rolinski was additionally funded by the FUME project FP7/243888. We thank Alison Schlums for English proofreading; all remaining errors are solely ours. Fruitful exchanges and discussions with Sibyll Schaphoff, Jens Heinke and Christoph Müller are appreciated. Following the persuasion of an anonymous reviewer, we included the closer look into the underlying mechanisms and are very thankful for this considerable improvement of the manuscript.

Edited by: J. M. Moreno

\section{References}

Anav, A. and Mariotti, A.: Sensitivity of natural vegetation to climate change in the Euro-Mediterranean area, Clim. Res., 46, 277-292, 2011.

Barbeta, A., Ogaya, R., and Penuelas, J.: Dampening effects of long-term experimental drought on growth and mortality rates of a Holm oak forest, Glob. Change Biol., 19, 3133-3144, 2013.

Barnaba, F., Angelini, F., Curci, G., and Gobbi, G. P.: An important fingerprint of wildfires on the European aerosol load, Atmos. Chem. Phys., 11, 10487-10501, doi:10.5194/acp-1110487-2011, 2011.

Bedia, J., Herrera, S., Gutiérrez, J. M., Zavala, G., Urbieta, I. R., and Moreno, J. M.: Sensitivity of fire weather index to different reanalysis products in the Iberian Peninsula, Nat. Hazards Earth Syst. Sci., 12, 699-708, doi:10.5194/nhess-12-699-2012, 2012.

Beer, C., Weber, U., Tomelleri, E., Carvalhais, N., Mahecha, M., and Reichstein, M.: Harmonized European long-term climate data for assessing the effect of changing temporal variability on land-atmosphere $\mathrm{CO}_{2}$ fluxes, J. Climate, 27, 4815-4834, 2014.

Biemans, H., Hutjes, R., Kabat, P., Strengers, B., Gerten, D., and Rost, S.: Impacts of precipitation uncertainty on discharge calculations for main river basins, J. Hydrometeorol., 10, 1011-1025, 2009.

Bondeau, A., Smith, P. C., Zaehle, S., Schaphoff, S., Lucht, W., Cramer, W., and Gerten, D.: Modelling the role of agriculture for the 20th century global terrestrial carbon balance, Glob. Change Biol., 13, 679-706, 2007.

Buentgen, U., Tegel, W., Nicolussi, K., McCormick, M., Frank, D., Trouet, V., Kaplan, J. O., Herzig, F., Heussner, K.-U., Wanner, H., Luterbacher, J., and Esper, J.: 2500 Years of European Climate Variability and Human Susceptibility, Science, 331, 578582, 2011.

Bussotti, F. and Ferretti, M.: Air pollution, forest condition and forest decline in Southern Europe: an overview, Environ. Pollut., 101, 49-65, 1998.

Cherwin, K. and Knapp, A.: Unexpected patterns of sensitivity to drought in three semi-arid grasslands, Oecologia, 169, 845-852, 2012

Ciais, P., Reichstein, M., Viovy, N., Granier, A., Ogee, J., Allard, V., Aubinet, M., Buchmann, N., Bernhofer, C., Carrara, A., Chevallier, F., De Noblet, N., Friend, A., Friedlingstein, P., Grunwald, T., Heinesch, B., Keronen, P., Knohl, A., Krinner, G., Loustau,
D., Manca, G., Matteucci, G., Miglietta, F., Ourcival, J., Papale, D., Pilegaard, K., Rambal, S., Seufert, G., Soussana, J., Sanz, M., Schulze, E., Vesala, T., and Valentini, R.: Europe-wide reduction in primary productivity caused by the heat and drought in 2003, Nature, 437, 529-533, 2005.

Coumou, D. and Rahmstorf, S.: A decade of weather extremes, Nature Climate Change, 2, 491-496, 2012.

Dee, D. P., Uppala, S. M., Simmons, A. J., Berrisford, P., Poli, P., Kobayashi, S., Andrae, U., Balmaseda, M. A., Balsamo, G., Bauer, P., Bechtold, P., Beljaars, A. C. M., van de Berg, L., Bidlot, J., Bormann, N., Delsol, C., Dragani, R., Fuentes, M., Geer, A. J., Haimberger, L., Healy, S. B., Hersbach, H., Holm, E. V., Isaksen, L., Kallberg, P., Koehler, M., Matricardi, M., McNally, A. P., Monge-Sanz, B. M., Morcrette, J. J., Park, B. K., Peubey, C., de Rosnay, P., Tavolato, C., Thepaut, J. N., and Vitart, F.: The ERA-Interim reanalysis: configuration and performance of the data assimilation system, Q. J. Roy. Meteor. Soc., 137, 553-597, 2011.

Diez, J. M., Hulme, P. E., and Duncan, R. P.: Using prior information to build probabilistic invasive species risk assessments, Biol Invasions, 14, 681-691, 2012.

EFFIS: European Forest Fire Information System, http://forest.jrc. ec.europa.eu/effis/ (last access: 9 March 2015), 2014.

Eilmann, B., Zweifel, R., Buchmann, N., Pannatier, E. G., and Rigling, A.: Drought alters timing, quantity, and quality of wood formation in Scots pine, J. Exp. Bot., 62, 2763-2771, 2011.

Evangeliou, N., Balkanski, Y., Cozic, A., Hao, W. M., Mouillot, F., Thonicke, K., Paugam, R., Zibtsev, S., Mousseau, T. A., Wang, R., Poulter, B., Petkov, A., Yue, C., Cadule, P., Koffi, B., Kaiser, J. W., and Moller, A. P.: Fire evolution in the radioactive forests of Ukraine and Belarus: future risks for the population and the environment, Ecol. Monogr., 85, 49-72, 2015.

Farquhar, G. D. and Von Caemmerer, S.: Modelling of photosynthetic response to environmental conditions, in: Physiological Plant Ecology II: Water Relations and Carbon Assimilation, edited by: Nobel, P., 549-587, Springer, Berlin, 1982.

Farquhar, G. D., Caemmerer, S. V., and Berry, J. A.: A biochemical model of photosynthetic $\mathrm{CO}_{2}$ assimilation in leaves of $\mathrm{C} 3$ species, Planta, 149, 78-90, 1980.

Field, C. B., Barros, V., Stocker, T. F., and Dahe, Q.: Special Report on Managing the risks of Extreme Events and Disasters to Advance Climate Change Adaptation (SREX), Cambridge University Press, 2012.

Frank, D., Reichstein, M., Bahn, M., Frank, D., Mahecha, M. D., Smith, P., Thonicke, K., van der Velde, M., Vicca, S., Babst, F., Beer, C., Buchmann, N., Canadell, J. G., Ciais, P., Cramer, W., Ibrom, A., Miglietta, F., Poulter, B., Rammig, A., Seneviratne, S. I., Walz, A., Wattenbach, M., Zavala, M. A., and Zscheischler, J.: Effects of climate extremes on the terrestrial carbon cycle: concepts, observations and global implications, Glob. Change Biol., doi:10.1111/gcb.12916, 2015.

Garcia-Lopez, J. M. and Allue, C.: A phytoclimatic-based indicator for assessing the inherent responsitivity of the European forests to climate change, Ecol. Indic., 18, 73-81, 2012.

Gerten, D., Schaphoff, S., Haberlandt, U., Lucht, W., and Sitch, S.: Terrestrial vegetation and water balance - hydrological evaluation of a dynamic global vegetation model, J. Hydrol., 286, 249$270,2004$. 
Gerten, D., Schaphoff, S., and Lucht, W.: Potential future changes in water limitations of the terrestrial biosphere, Clim. Change, 80, 277-299, 2007.

Giglio, L., Randerson, J. T., van der Werf, G. R., Kasibhatla, P. S., Collatz, G. J., Morton, D. C., and DeFries, R. S.: Assessing variability and long-term trends in burned area by merging multiple satellite fire products, Biogeosciences, 7, 1171-1186, doi:10.5194/bg-7-1171-2010, 2010.

Haddeland, I., Clark, D. B., Franssen, W., Ludwig, F., Voss, F., Arnell, N. W., Bertrand, N., Best, M., Folwell, S., Gerten, D., Gomes, S., Gosling, S. N., Hagemann, S., Hanasaki, N., Harding, R., Heinke, J., Kabat, P., Koirala, S., Oki, T., Polcher, J., Stacke, T., Viterbo, P., Weedon, G. P., and Yeh, P.: Multimodel Estimate of the Global Terrestrial Water Balance: Setup and First Results, J. Hydrometeorol., 12, 869-884, 2011.

Hope, B. K.: Generating probabilistic spatially-explicit individual and population exposure estimates for ecological risk assessments, Risk Anal., 20, 573-589, 2000.

Ionescu, C., Klein, R. J. T., Hinkel, J., Kumar, K. S. K., and Klein, R.: Towards a Formal Framework of Vulnerability to Climate Change, Environ. Model. Assess., 14, 1-16, 2009.

IPCC: Managing the Risks of Extreme Events and Disasters to Advance Climate Change Adaptation, Cambridge University Press, Cambridge, UK, and New York, NY, USA, A Special Report of Working Groups I and II of the Intergovernmental Panel on Climate Change, 2012.

Jung, M., Reichstein, M., Margolis, H. A., Cescatti, A., Richardson, A. D., Arain, M. A., Arneth, A., Bernhofer, C., Bonal, D., Chen, J., Gianelle, D., Gobron, N., Kiely, G., Kutsch, W., Lasslop, G., Law, B. E., Lindroth, A., Merbold, L., Montagnani, L., Moors, E. J., Papale, D., Sottocornola, M., Vaccari, F., and Williams, C.: Global patterns of land-atmosphere fluxes of carbon dioxide, latent heat, and sensible heat derived from eddy covariance, satellite, and meteorological observations, J. Geophys. Res.-Biogeo., 116, G00J07, doi:10.1029/2010JG001566, 2011.

Keeling, C. D. and Whorf, T. P.: Atmospheric $\mathrm{CO}_{2}$ records from sites in the SIO air sampling network, in: Trends: A Compendium of Data on Global Change, Carbon Dioxide Information Analysis Center, Oak Ridge National Laboratory, US Department of Energy, Oak Ridge, Tenn., USA, 2005.

Martin-StPaul, N. K., Limousin, J.-M., Vogt-Schilb, H., RodriguezCalcerrada, J., Rambal, S., Longepierre, D., and Misson, L.: The temporal response to drought in a Mediterranean evergreen tree: comparing a regional precipitation gradient and a throughfall exclusion experiment, Glob. Change Biol., 19, 2413-2426, 2013.

Misson, L., Degueldre, D., Collin, C., Rodriguez, R., Rocheteau, A., Ourcival, J.-M., and Rambal, S.: Phenological responses to extreme droughts in a Mediterranean forest, Glob. Change Biol., 17, 1036-1048, 2011.

Murray, S. J., Watson, I. M., and Prentice, I. C.: The use of dynamic global vegetation models for simulating hydrology and the potential integration of satellite observations, Prog. Phys. Geog., 37, 63-97, 2013.

Nesterov, V. G.: Gorimost' Lesa I Metody Eio Opredelenia, Moscow: Goslesbumaga, 1949.

Piovesan, G., Biondi, F., Di Filippo, A., Alessandrini, A., and Maugeri, M.: Drought-driven growth reduction in old beech $(\mathrm{Fa}$ gus sylvatica L.) forests of the central Apennines, Italy, Glob. Change Biol., 14, 1265-1281, 2008.
R Development Core Team: R: A Language and Environment for Statistical Computing, R Foundation for Statistical Computing, Vienna, Austria, http://www.R-project.org, ISBN 3-900051-070, 2014.

Rammig, A., Wiedermann, M., Donges, J. F., Babst, F., von Bloh, W., Frank, D., Thonicke, K., and Mahecha, M. D.: Coincidences of climate extremes and anomalous vegetation responses: comparing tree ring patterns to simulated productivity, Biogeosciences, 12, 373-385, doi:10.5194/bg-12-373-2015, 2015.

Regan, H. M., Akcakaya, H. R., Ferson, S., Root, K. V., Carroll, S., and Ginzburg, L. R.: Treatments of uncertainty and variability in ecological risk assessment of single-species populations, Human and Ecological Risk Assessment, 9, 889-906, 2003.

Reichstein, M., Ciais, P., Papale, D., Valentini, R., Running, S., Viovy, N., Cramer, W., Granier, A., Ogee, J., Allard, V., Aubinet, M., Bernhofer, C., Buchmann, N., Carrara, A., Grunwald, T., Heimann, M., Heinesch, B., Knohl, A., Kutsch, W., Loustau, D., Manca, G., Matteucci, G., Miglietta, F., Ourcival, J. M., Pilegaard, K., Pumpanen, J., Rambal, S., Schaphoff, S., Seufert, G., Soussana, J. F., Sanz, M. J., Vesala, T., and Zhao, M.: Reduction of ecosystem productivity and respiration during the European summer 2003 climate anomaly: a joint flux tower, remote sensing and modelling analysis, Glob. Change Biol., 13, 634-651, 2007.

Reichstein, M., Bahn, M., Ciais, P., Frank, D., Mahecha, M. D., Seneviratne, S. I., Zscheischler, J., Beer, C., Buchmann, N., Frank, D. C., Papale, D., Rammig, A., Smith, P., Thonicke, K., van der Velde, M., Vicca, S., Walz, A., and Wattenbach, M.: Climate extremes and the carbon cycle, Nature, 500, 287-295, 2013.

Rost, S., Gerten, D., Bondeau, A., Lucht, W., Rohwer, J., and Schaphoff, S.: Agricultural green and blue water consumption and its influence on the global water system, Water Resour. Res., 44, W09405, doi:10.1029/2007WR006331, 2008.

Schaphoff, S., Heyder, U., Ostberg, S., Gerten, D., Heinke, J., and Lucht, W.: Contribution of permafrost soils to the global carbon budget, Environ. Res. Lett., 8, 014026, doi:10.1088/17489326/8/1/014026, 2013.

Schulze, E.-D.: Biological control of the terrestrial carbon sink, Biogeosciences, 3, 147-166, doi:10.5194/bg-3-147-2006, 2006.

Seneviratne, S. I., Nicholls, N., Easterling, D., Goodess, C. M., Kanae, S., Kossin, J., Luo, Y., Marengo, J., McInnes, K. Rahimi, M., Reichstein, M., Sorteberg, A., Vera, C., and Zhan, X.: Changes in climate extremes and their impacts on the natural physical environment, in: Managing the Risks of Extreme Events and Disasters to Advance Climate Change Adaptation. A Special Report of Working Groups I and II of the Intergovernmental Panel on Climate Change (IPCC SREX Report), edited by: Field, C. B., Barros, V., Stocker, T. F., Qin, D., Dokken, D. J., Ebi, K. L., Mastrandrea, M. D., Mach, K. J., Plattner, G.-K., Allen, S. K., Tignor, M., and Midgley, P. M., 109-230, Cambridge University Press, Cambridge (UK), New York (USA), 2012.

Sitch, S., Smith, B., Prentice, I., Arneth, A., Bondeau, A., Cramer, W., Kaplan, J. O., Levis, S., Lucht, W., Sykes, M. T., Thonicke, K., and Venevsky, S.: Evaluation of ecosystem dynamics, plant geography and terrestrial carbon cycling in the LPJ dynamic global vegetation model, Glob. Change Biol., 9, 161-185, 2003. 
Smith, M. D.: An ecological perspective on extreme climatic events: a synthetic definition and framework to guide future research, J. Ecol., 99, 656-663, 2011.

Thonicke, K., Spessa, A., Prentice, I. C., Harrison, S. P., Dong, L., and Carmona-Moreno, C.: The influence of vegetation, fire spread and fire behaviour on biomass burning and trace gas emissions: results from a process-based model, Biogeosciences, 7, 1991-2011, doi:10.5194/bg-7-1991-2010, 2010.

Ulevicius, V., Bycenkiene, S., Remeikis, V., Garbaras, A., Kecorius, S., Andriejauskiene, J., Jasineviciene, D., and Mocnik, G.: Characterization of pollution events in the East Baltic region affected by regional biomass fire emissions, Atmos. Res., 98, 190-200, 2010.

van der Werf, G. R., Randerson, J. T., Giglio, L., Collatz, G. J., Mu, M., Kasibhatla, P. S., Morton, D. C., DeFries, R. S., Jin, Y., and van Leeuwen, T. T.: Global fire emissions and the contribution of deforestation, savanna, forest, agricultural, and peat fires (19972009), Atmos. Chem. Phys., 10, 11707-11735, doi:10.5194/acp10-11707-2010, 2010.

Van Oijen, M., Beer, C., Cramer, W., Rammig, A., Reichstein, M., Rolinski, S., and Soussana, J.-F.: A novel probabilistic risk analysis to determine the vulnerability of ecosystems to extreme climatic events, Environ. Res. Lett., 8, 015032, doi:10.1088/17489326/8/1/015032, 2013.

Van Oijen, M., Balkovi, J., Beer, C., Cameron, D. R., Ciais, P., Cramer, W., Kato, T., Kuhnert, M., Martin, R., Myneni, R., Rammig, A., Rolinski, S., Soussana, J.-F., Thonicke, K., Van der Velde, M., and Xu, L.: Impact of droughts on the carbon cycle in European vegetation: a probabilistic risk analysis using six vegetation models, Biogeosciences, 11, 6357-6375, doi:10.5194/bg11-6357-2014, 2014.

Vicente-Serrano, S. M., Begueria, S., and Lopez-Moreno, J. I.: A Multiscalar Drought Index Sensitive to Global Warming: The Standardized Precipitation Evapotranspiration Index - SPEI, J. Climate, 23, 1696-1718, 2010
Vicente-Serrano, S. M., Gouveia, C., Camarero, J. J., Begueria, S., Trigo, R., Lopez-Moreno, J. I., Azorin-Molina, C., Pasho, E., Lorenzo-Lacruz, J., Revuelto, J., Moran-Tejeda, E., and SanchezLorenzo, A.: Response of vegetation to drought time-scales across global land biomes, P. Natl. Acad. Sci. USA, 110, 52-57, 2012.

Wagner, W., Scipal, K., Pathe, C., Gerten, D., Lucht, W., and Rudolf, B.: Evaluation of the agreement between the first global remotely sensed soil moisture data with model and precipitation data, J. Geophys. Res., 108, 4611, doi:10.1029/2003JD003663, 2003.

Wall, I. B.: Probabilistic Assessment of Risk for Reactor Design and Siting, T. Am. Nucl. Soc., 12, 169-169, 1969.

Weedon, G., Gomes, S., Viterbo, P., Shuttleworth, W. J., Blyth, E., Osterle, H., Adam, J., Bellouin, N., Boucher, O., and Best, M.: Creation of the WATCH Forcing Data and Its Use to Assess Global and Regional Reference Crop Evaporation over Land during the Twentieth Century, J. Hydrometeorol., 12, 823-848, 2011.

Wilson, D. S., Stoddard, M. A., Betts, M. G., and Puettmann, K. J.: Bayesian Small Area Models for Assessing Wildlife Conservation Risk in Patchy Populations, Conserv. Biol., 23, 982-991, 2009.

Zscheischler, J., Mahecha, M. D., Buttlar, J. v., Harmeling, S., Jung, M., Rammig, A., Randerson, J. T., Schoelkopf, B., Seneviratne, S. I., Tomelleri, E., Zaehle, S., and Reichstein, M.: A few extreme events dominate global interannual variability in gross primary production, Environ. Res. Lett., 9, 035001, doi:10.1088/17489326/9/3/035001, 2014a.

Zscheischler, J., Reichstein, M., Harmeling, S., Rammig, A., Tomelleri, E., and Mahecha, M. D.: Extreme events in gross primary production: a characterization across continents, Biogeosciences, 11, 2909-2924, doi:10.5194/bg-11-2909-2014, 2014b. 